\title{
The genus Ravenelia (Pucciniales) in South Africa
}

\author{
Malte Ebinghaus $^{1}\left(\right.$ D $\cdot$ M. J. Wingfield ${ }^{2} \cdot$ D. Begerow ${ }^{1} \cdot$ W. Maier ${ }^{3}$
}

Received: 23 August 2019 / Revised: 30 December 2019 / Accepted: 2 January 2020

(C) The Author(s) 2020

\begin{abstract}
The genus Ravenelia represents the third largest genus of rust fungi and parasitizes a great number of leguminous shrubs and trees, mainly in the subtropics and tropics. Molecular phylogenetic analyses of this genus using nc 28S rDNA and CO3 sequences are presented with a special focus on South African representatives of Ravenelia. Many of the specimens had been collected by us in recent years, mainly from acacia species of the genera Vachellia and Senegalia. Morphological characters were extensively studied using light microscopy and scanning electron microscopy. The analyses resolved several well-supported phylogenetic groups. By linking these groups to their morphology and life cycle characteristics, it was possible to interpret the outcomes in terms of their evolutionary ecology and biogeography. Several characters previously used to define subgeneric groups within Ravenelia were found to be misleading because of assumed convergent evolution. However, host associations, the ability to induce aecial galls as well as the development of two-layered probasidial cells emerged as useful criteria for inferring monophyletic groups. Six novel Ravenelia species were discovered and described. Furthermore, five species represent new reports for South Africa, species descriptions were emended for two taxa, and a new host report emerged for $R$. inornata.
\end{abstract}

Keywords Pucciniales · Raveneliaceae - Ravenelia moloto sp. nov. · Ravenelia molopa sp. nov. · Ravenelia modjadji sp. nov · Ravenelia doidgeae sp. nov. · Ravenelia spinifera sp. nov. · Ravenelia dumeti sp. nov. · Phylogeny · Diversity study

\section{Introduction}

In 1853 , Berkeley introduced the genus Ravenelia within the rust fungi (Pucciniales). The genus initially comprised two species: R. glandulosa Berk. \& M.A. Curtis, which was transferred from

This article is part of the topical collection on Basidiomycote Mycology in honor of Franz Oberwinkler who passed away in March 2018

Section Editor: Meike Piepenbring

Electronic supplementary material The online version of this article (https://doi.org/10.1007/s11557-020-01556-w) contains supplementary material, which is available to authorized users.

Malte Ebinghaus

malte.ebinghaus@gmx.de

1 AG Geobotanik, Ruhr-Universität Bochum, Bochum, Germany

2 FABI Forestry and Agricultural Biotechnology Institute, University of Pretoria, Pretoria, South Africa

3 Institute for Epidemiology and Pathogen Diagnostics, Federal Research Centre for Cultivated Plants, Julius Kühn-Institut, Braunschweig, Germany
Sphaeria epiphylla Schwein. collected on Tephrosia virginiana (L.) Pers. in South Carolina and the newly described $R$. indica Berk. found on pods of an unidentified acacia. Later then Dietel correctly recombined the type species $R$. glandulosa to $R$. epiphylla (Schwein.) Dietel (Dietel 1894). In subsequent years, many additional Ravenelia species were found throughout the tropics and subtropics and today, some 200 species are described (Hernández and Hennen 2002, Cummins and Hiratsuka 2003). Ravenelia thus became the third most species-rich rust fungal genus after Puccinia and Uromyces.

All known species of Ravenelia are confined to a great diversity of Fabaceae residing in all three traditionally recognized subfamilies (Mimosoideae, Faboideae, Caesalpinioideae) (Hennen et al. 2005). The most prominent morphological features that are shared by all species of Ravenelia are the multicellular teliospores, which are borne on compound pedicels composed of two to several hyphae. These spores have an ellipsoidal, reniform, or almost hemispherical shape in side view and bear a variable number of pendent hygroscopic cysts. Other characters include spermogonia of type 5 and 7 (Cummins and Hiratsuka 2003) but these are commonly absent.

All species of Ravenelia are autoecious and their life cycles range from macro- and demi to hemi-, and more rarely to 
microcyclic (Cummins and Hiratsuka 2003). The aecial stage of several macrocyclic Ravenelia spp. can easily be recognized in the field by their ability to induce galls and witches' brooms in host tissues. Another special feature is the production of uredinoid aecia in numerous species of Ravenelia (Cummins 1959; Cummins and Hiratsuka 2003).

The morphological diversity and the variability of Ravenelia life cycles prompted mycologists early in the twentieth century to establish sections (Long 1903; Dietel 1906) or even to split this genus into several distinct genera (Sydow and Sydow 1915; Sydow 1921). The most sophisticated taxonomic system for Ravenelia was proposed by Sydow (1921) distinguishing eight genera based on teliospore traits in combination with observed life cycles. Details of the competing taxonomic systems are summarized in Table S1. However, a broad genus concept of Ravenelia comprising all these suggested genera or sections (within one genus) remains most widely accepted (compare Cummins and Hiratsuka 2003).

More than 500 rust species are known from South Africa (Crous et al. 2006), making this country relatively well explored for these fungi in comparison with other countries in Africa. Most contributions to the collection and description of rust fungi in South Africa are attributed to the investigations of Ethel M. Doidge during the first half of the twentieth century. In her last comprehensive species list of southern African rust fungi, she mentioned 24 Ravenelia species eight of which she described (Doidge 1927, 1939, 1950). The most recent species list was published by van Reenen (1995) but nearly exclusively relied on literature data provided by Doidge. Due to changes in political borders, two species each now only occur in Mozambique $(R$. deformans and $R$. le-testui) and Zimbabwe (R. indigoferae and $R$. bottomleyae) respectively, while $R$. baumiana was recorded only from Angola. Two rusts, $R$. atrides and $R$. bottomleyae, were transferred to the genera Uredopeltis (Wood 2007) and Spumula (Thirumalachar 1946), respectively. Wood (2006) recorded R. ornata for the first time in South Africa and Ebinghaus et al. (2018) described $R$. xanthophloeae on the Vachellia xanthophloea. Thus, 19 Ravenelia species are currently known for South Africa.

During the course of recent surveys, aiming at recollecting the majority of Ravenelia species from South Africa and especially at investigating all known Acacia s.l. for potential rust infections, we have collected numerous specimens from acacias and fabaceous plants. The overarching aims were to re-evaluate the species diversity and systematics of Ravenelia rusts in South Africa by using microscopic investigations and molecular phylogenetic techniques. For a better understanding of the phylogeny of the genus as a whole also species mainly from the Neotropics were investigated. The emerging phylogenetic clades were interpreted using aspects of biogeographical distributions, life cycle traits, and host associations as well as morphological data. Furthermore, in order to illustrate conflicts when applying the taxonomic system for Ravenelia proposed by Sydow (1921), we mapped his suggested nomenclatural system to the phylogenetic reconstructions and discussed these outcomes.

\section{Material and methods}

\section{Specimens examined}

The specimens used for the molecular phylogenetic and morphological analyses were collected during several field surveys from 2004 to 2015 in South Africa. In addition, we considered 13 herbarium specimens from BPI originating from North and South America as well as DNA sequences downloaded from GenBank (see Table 1). Freshly collected material was immediately dried between paper sheets in a plant press and deposited after determination at the National Collections of Fungi (PREM) in Roodeplaat, South Africa, and the herbarium of the Natural History Museum in Karlsruhe (KR), Germany. In total, 91 specimens representing 44 Ravenelia species and three outgroup species were included in the molecular phylogenetic analyses and all of them were examined microscopically. For comparative purposes, additional 32 specimens comprising 15 type specimens deposited at PREM were examined only microscopically. All specimens investigated in this study are listed in Table 1.

\section{Light- and electron microscopic investigations}

The spores from plant material were scraped from the infected tissues using sterile insect needles and mounted in lactophenol solution on microscope slides. Light microscopic examinations were made using a Zeiss Axioplan light microscope (Carl Zeiss Microscopy, Jena, Germany) with a Color View microscope camera (Olympus Soft Imaging System, Münster, Germany) and a Zeiss Axio Imager M2 microscope with an Axiocam 506 camera (both Carl Zeiss Microscopy, Jena, Germany). Morphological characteristics were measured using Cell^ $\mathrm{D}$ v. 3.1 imaging software (Olympus Soft Imaging Solutions $\mathrm{GmbH}$, Münster, Germany) and Zen2 Blue Edition v.2.3 (Carl Zeiss Microscopy GmbH, Jena, Germany). The specimens comprising Ravenelia albizziicola (PREM40295), R. baumiana (PREM50553, PREM29870, PREM6886), $R$. elephantorhizae (PREM8955), $R$. escharoides (PREM534), R. glabra (PREM2375, PREM10698), R. halsei (PREM30117, PREM50751), R. inornata (PREM2368, PREM2541, PREM20734), R. minima (PREM30779, PREM10697), R. modesta (PREM34572, PREM30110), R. natalensis (PREM2514, PREM1935), $R$. peglerae (PREM2544, PREM5626, PREM2331), $R$. pienaarii (PREM5627, PREM6658), $R$. 
Table 1 List of specimens used in this study

\begin{tabular}{|c|c|c|c|c|c|}
\hline \multirow[t]{2}{*}{ Fungus } & \multirow[t]{2}{*}{ Host } & \multirow[t]{2}{*}{ Location } & \multirow[t]{2}{*}{ Voucher } & \multicolumn{2}{|c|}{ GenBank accession } \\
\hline & & & & $L S U$ & $\mathrm{CO} 3$ \\
\hline $\begin{array}{l}\text { Ravenelia } \\
\quad \text { acaciae-arabicae }\end{array}$ & Vachellia nilotica & $\begin{array}{l}\text { South Africa, KwaZulu-Natal, } \\
\text { Weenen Game Reserve }\end{array}$ & KR-M-0006425* & - & - \\
\hline $\begin{array}{l}\text { Ravenelia } \\
\quad \text { acaciae-arabicae }\end{array}$ & Vachellia nilotica & $\begin{array}{l}\text { South Africa, KwaZulu-Natal, } \\
\text { S } 29^{\circ} 49^{\prime} 29.1^{\prime \prime} \text {, E } 30^{\circ} 32^{\prime} 08.5^{\prime \prime}\end{array}$ & PREM61853 & MN072675 & - \\
\hline $\begin{array}{l}\text { Ravenelia } \\
\quad \text { acaciae-arabicae }\end{array}$ & Vachellia nilotica & $\begin{array}{l}\text { South Africa, KwaZulu-Natal, } \\
\quad \text { S } 30^{\circ} 01^{\prime} 07.2^{\prime \prime} \text {, E } 30^{\circ} 13^{\prime} 58.7^{\prime \prime}\end{array}$ & PREM61854 & MN072674 & MN095319 \\
\hline $\begin{array}{l}\text { Ravenelia } \\
\quad \text { acaciae-nigrescentis }\end{array}$ & Senegalia nigrescens & $\begin{array}{l}\text { South Africa, Mpumalanga, } \\
\text { KNP, Orpen Rest Camp }\end{array}$ & KR-M-0006413 & MN072686 & MN095329 \\
\hline $\begin{array}{l}\text { Ravenelia } \\
\quad \text { acaciae-nigrescentis }\end{array}$ & Senegalia nigrescens & $\begin{array}{l}\text { South Africa, Mpumalanga, } \\
\text { KNP, Orpen Rest Camp }\end{array}$ & KR-M-0006619 & MN072685 & - \\
\hline $\begin{array}{l}\text { Ravenelia } \\
\quad \text { acaciae-pennatulae }\end{array}$ & Vachellia pennatula & $\begin{array}{l}\text { Mexico, Veracruz Province, } \\
\mathrm{N} 19^{\circ} 26^{\prime} 44.1^{\prime \prime}, \mathrm{W} 96^{\circ} 49^{\prime} 51.9^{\prime \prime}\end{array}$ & BPI864189 & MN072655 & MN095299 \\
\hline Ravenelia acaciicola & Senegalia senegal var leiorhachis & $\begin{array}{l}\text { South Africa, Zwemkloof, } \\
\text { Motse-River, Sekhukhuneland }\end{array}$ & PREM61891 & MN072689 & - \\
\hline Ravenelia acaciicola & Senegalia senegal var. leiorhachis & $\begin{array}{l}\text { South Africa, Mpumalanga, } \\
\text { Komatipoort }\end{array}$ & PREM60999 & MN072671 & - \\
\hline Ravenelia acaciicola & Senegalia senegal var leiorhachis & $\begin{array}{l}\text { South Africa, Limpopo, } \\
\text { Steelport, S } 24^{\circ} 44^{\prime} 00.6^{\prime \prime} \\
\text { E } 30^{\circ} 13^{\prime} 25.1^{\prime \prime}\end{array}$ & PREM61861 & MN072683 & MN095326 \\
\hline Ravenelia acaciicola & Senegalia senegal var rostrata & $\begin{array}{l}\text { South Africa, KwaZulu-Natal, } \\
\text { S } 27^{\circ} 29^{\prime} 27.7^{\prime \prime} \text {, E } 32^{\circ} 11^{\prime} 37.5^{\prime \prime}\end{array}$ & PREM61847 & MN072677 & MN095320 \\
\hline Ravenelia acaciicola & Senegalia senegal var rostrata & $\begin{array}{l}\text { South Africa, KwaZulu-Natal, } \\
\text { S } 27^{\circ} 40^{\prime} 49.3^{\prime \prime} \text {, E } 32^{\circ} 25^{\prime} 24.0^{\prime \prime}\end{array}$ & PREM61849 & MN072676 & - \\
\hline Ravenelia albizziicola* & Albizia harveyi & - & PREM40295** & - & - \\
\hline Ravenelia argentinica & Vachellia aroma & $\begin{array}{l}\text { Argentina, Jujuy Province, } \\
\text { Parque Nacional Calilegua }\end{array}$ & BPI841267 & MN072654 & MN095296 \\
\hline Ravenelia argentinica & Vachellia aroma & $\begin{array}{l}\text { Argentina, Salta Province, } \\
\text { road to Parque del Rey }\end{array}$ & BPI841256 & MN072653 & MN095298 \\
\hline Ravenelia baumiana* & Senna petersiana & - & PREM50553* & - & - \\
\hline Ravenelia baumiana* & Senna delagoensis & - & PREM29870* & - & - \\
\hline Ravenelia baumiana* & Senna singueana & Angola & PREM6886*/** & - & - \\
\hline Ravenelia cebil & Anadenanthera sp. & $\begin{array}{l}\text { Argentina, Tucuman Province, } \\
\text { San Pedro de Colalao }\end{array}$ & BPI841029 & MN072649 & - \\
\hline Ravenelia cohniana & Senegalia praecox & $\begin{array}{l}\text { Argentina, Catamarca Province, } \\
\text { Rio Las Juntas }\end{array}$ & BPI841185 & MG954487 & - \\
\hline Ravenelia dichrostachydis & Dichrostachys cinerea & $\begin{array}{l}\text { South Africa, Mpumalanga, } \\
\text { Nelspruit, SANBI }\end{array}$ & KR-M-0006448 & MN072690 & MN095332 \\
\hline Ravenelia doidgeae & $\begin{array}{l}\text { Senegalia polyacantha subsp. } \\
\quad \text { polyacantha }\end{array}$ & $\begin{array}{l}\text { South Africa, Mpumalanga, } \\
\text { Nelspruit, Parking area } \\
\text { of Botanical Garden }\end{array}$ & PREM60992** & MN072672 & MN095316 \\
\hline Ravenelia dumeti & Senegalia brevispica & $\begin{array}{l}\text { South Africa, Mpumalanga, } \\
\text { S } 25^{\circ} 54^{\prime} 29.8^{\prime \prime}, \text { E } 31^{\circ} 53^{\prime} 48.5^{\prime \prime}\end{array}$ & ME406** & MN072680 & - \\
\hline Ravenelia dumeti & Senegalia brevispica & $\begin{array}{l}\text { South Africa, Mpumalanga, } \\
\text { S } 25^{\circ} 54^{\prime} 29.8^{\prime \prime} \text {, E } 31^{\circ} 53^{\prime} 48.5^{\prime \prime}\end{array}$ & PREM61877** & MN072681 & MN095324 \\
\hline $\begin{array}{l}\text { Ravenelia echinata var } \\
\quad \text { ectypa }\end{array}$ & Calliandra formosa & $\begin{array}{l}\text { Argentina, Tucuman Province, } \\
\text { San Pedro de Colalao }\end{array}$ & BPI841034 & DQ323925 & - \\
\hline Ravenelia elephantorhizae & Elephantorrhiza burkei & $\begin{array}{l}\text { South Africa, North-West } \\
\text { Province, Mountain Sanctuary } \\
\text { Park }\end{array}$ & KR-M-0006449 & MN072702 & MN095341 \\
\hline $\begin{array}{l}\text { Ravenelia } \\
\quad \text { elephantorhizae* }\end{array}$ & Elephantorrhiza elephantina & $\begin{array}{l}\text { South Africa, Gauteng, Pretoria, } \\
\text { Koedoespoort }\end{array}$ & PREM8955*/** & - & - \\
\hline Ravenelia escharoides & Senegalia burkei & $\begin{array}{l}\text { South Africa, Mpumalanga, } \\
\text { Blyde River Canyon }\end{array}$ & KR-M-0043650 & MG954480 & MN095330 \\
\hline Ravenelia escharoides & Senegalia burkei & $\begin{array}{l}\text { South Africa, Limpopo, } \\
\text { John Reservoir }\end{array}$ & KR-M-0043652 & MG954479 & - \\
\hline Ravenelia escharoides & Senegalia burkei & $\begin{array}{l}\text { South Africa, Limpopo, } \\
\text { Waterberge, Waterberg } \\
\text { Hiking Trail }\end{array}$ & KR-M-0043651 & MG954481 & - \\
\hline
\end{tabular}


Table 1 (continued)

\begin{tabular}{|c|c|c|c|c|c|}
\hline \multirow[t]{2}{*}{ Fungus } & \multirow[t]{2}{*}{ Host } & \multirow[t]{2}{*}{ Location } & \multirow[t]{2}{*}{ Voucher } & \multicolumn{2}{|c|}{ GenBank accession } \\
\hline & & & & $L S U$ & $\mathrm{CO} 3$ \\
\hline Ravenelia escharoides* & Senegalia burkei & $\begin{array}{l}\text { South Africa, Gauteng, } \\
\text { Pretoria Pienaars River }\end{array}$ & PREM29918* & - & - \\
\hline Ravenelia escharoides* & Senegalia burkei & $\begin{array}{l}\text { South Africa, Gauteng, } \\
\text { Pretoria, Near Hartebeestpoort } \\
\text { Dam }\end{array}$ & PREM27586* & - & - \\
\hline Ravenelia escharoides* & Senegalia burkei & $\begin{array}{l}\text { South Africa, Limpopo, } \\
\text { Pruizen (near Mokopane) }\end{array}$ & PREM534*/** & - & - \\
\hline Ravenelia evansii & Vachellia robusta subsp. robusta & $\begin{array}{l}\text { South Africa, KwaZulu-Natal, } \\
\text { False Bay }\end{array}$ & PREM61209 & MG945991 & - \\
\hline Ravenelia evansii & Vachellia robusta subsp. robusta & $\begin{array}{l}\text { South Africa, North-West } \\
\text { Province, Groot Marico, } \\
\text { River Still Guest Farm }\end{array}$ & PREM61208 & MG945992 & - \\
\hline Ravenelia evansii & Vachellia davyi & $\begin{array}{l}\text { South Africa, Mpumalanga, } \\
\text { R40 north of Nelspruit }\end{array}$ & PREM61224 & MN275523 & - \\
\hline Ravenelia evansii & Vachellia davyi & $\begin{array}{l}\text { South Africa, KwaZulu-Natal, } \\
\text { S } 27^{\circ} 19^{\prime} 27.2^{\prime \prime} \text {, E } 31^{\circ} 26^{\prime} 39.6^{\prime \prime}\end{array}$ & PREM61845 & MG946000 & MN095322 \\
\hline Ravenelia evansii & Vachellia sieberiana var woodii & $\begin{array}{l}\text { South Africa, Mpumalanga, } \\
\text { S } 25^{\circ} 23^{\prime} 41.8^{\prime \prime} \text {, E } 31^{\circ} 05^{\prime} 08.0^{\prime \prime}\end{array}$ & PREM61881 & MG945987 & - \\
\hline Ravenelia evansii & Vachellia hebeclada & $\begin{array}{l}\text { South Africa, North-West Province, } \\
\text { Leeuwfontein Farm }\end{array}$ & PREM61227 & MG946001 & - \\
\hline Ravenelia evansii & Vachellia swazica & $\begin{array}{l}\text { South Africa, Mpumalanga, } \\
\text { Marloth Park, S } 25^{\circ} 20^{\prime} 44.4^{\prime \prime} \text {, } \\
\text { E } 31^{\circ} 46^{\prime} 26.1^{\prime \prime}\end{array}$ & PREM61028 & MG945996 & - \\
\hline Ravenelia evansii & Vachellia exuvialis & $\begin{array}{l}\text { South Africa, Mpumalanga, } \\
\quad \mathrm{S} 24^{\circ} 52^{\prime} 52.6^{\prime \prime}, \text { E } 31^{\circ} 23^{\prime} 40.3^{\prime \prime}\end{array}$ & PREM61868 & MG945995 & - \\
\hline Ravenelia evansii & Vachellia borleae & $\begin{array}{l}\text { South Africa, KwaZulu-Natal, } \\
\text { S } 28^{\circ} 41^{\prime} 30.1^{\prime \prime} \text {, E } 31^{\circ} 43^{\prime} 16.9^{\prime \prime}\end{array}$ & ME384 & MG946003 & - \\
\hline Ravenelia evansii & Vachellia luederitzii var. retinens & $\begin{array}{l}\text { South Africa, KwaZulu-Natal, } \\
\text { S } 27^{\circ} 19^{\prime} 30^{\prime} 57.3^{\prime \prime} \text {, E } 32^{\circ} 00^{\prime} \\
39.1^{\prime \prime}\end{array}$ & PREM61846 & MG945993 & MN095321 \\
\hline Ravenelia glabra & Calpurnea aurea & $\begin{array}{l}\text { South Africa, KwaZulu-Natal, } \\
\text { Camperdown Game Farm }\end{array}$ & KR-M-0006450 & MN072691 & MN095333 \\
\hline Ravenelia glabra* & Calpurnea sylvatica & $\begin{array}{l}\text { South Africa, KwaZulu-Natal, } \\
\text { Muden }\end{array}$ & PREM2375*/** & - & - \\
\hline Ravenelia glabra* & Calpurnea sylvatica & - & PREM10698*/** & - & - \\
\hline Ravenelia halsei & Senegalia ataxacantha & $\begin{array}{l}\text { South Africa, Nelspruit, } \\
\text { Botanical Garden }\end{array}$ & KR-M-0006620* & - & - \\
\hline Ravenelia halsei & Senegalia ataxacantha & $\begin{array}{l}\text { South Africa, KwaZulu-Natal, } \\
\text { S } 29^{\circ} 39^{\prime} 13.8^{\prime \prime} \text {, E } 30^{\circ} 26^{\prime} 59.2^{\prime \prime}\end{array}$ & KR-M-0006444* & - & - \\
\hline Ravenelia halsei & Senegalia ataxacantha & $\begin{array}{l}\text { South Africa, KwaZulu-Natal, } \\
\text { close to Oribi Gorge }\end{array}$ & PREM61855 & MG954484 & - \\
\hline Ravenelia halsei & Senegalia ataxacantha & $\begin{array}{l}\text { South Africa, Mpumalanga, } \\
\quad \text { S } 25^{\circ} 02^{\prime} 33.4^{\prime \prime}, \text { E } 31^{\circ} 06^{\prime} 10.3^{\prime \prime}\end{array}$ & PREM61867 & MN072682 & MN095325 \\
\hline Ravenelia halsei* & Senegalia ataxacantha & $\begin{array}{l}\text { South Africa, Mpumalanga, } \\
60 \mathrm{~km} \text { south of Nelspruit }\end{array}$ & PREM50751 & - & - \\
\hline Ravenelia halsei* & Senegalia ataxacantha & $\begin{array}{l}\text { South Africa, KwaZulu-Natal, } \\
\text { Ndwedwe }\end{array}$ & PREM30117** & - & - \\
\hline Ravenelia havanensis & Enterolobium cyclocarpum & 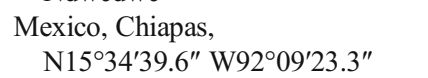 & BPI871922 & MN275524 & MN095301 \\
\hline Ravenelia hermosa & Leucaena sp. & Colombia & BPI1107966 & MN072657 & MN095304 \\
\hline Ravenelia hernandezii & Senegalia tenuifolia & $\begin{array}{l}\text { Costa Rica, Guanacaste Province, } \\
\mathrm{N} 10^{\circ} 50^{\prime} 42.1^{\prime \prime}, \mathrm{W} 85^{\circ} 36^{\prime} 27.0^{\prime \prime}\end{array}$ & BPI872308 & MG954488 & MN095304 \\
\hline Ravenelia hieronymi & Vachellia caven & $\begin{array}{l}\text { Argentina, Tucuman Province, } \\
\quad \mathrm{S} 27^{\circ} 40^{\prime} 38.0^{\prime \prime}, \mathrm{W} 65^{\circ} 46^{\prime} 49.4^{\prime \prime}\end{array}$ & BPI841165 & MN072651 & - \\
\hline Ravenelia holwayi & Prosopis glandulosa & $\begin{array}{l}\text { USA, Texas, Del Rio. North Hill/20 } \\
\text { Rico }\end{array}$ & BPI871145 & MN072656 & MN095300 \\
\hline Ravenelia holwayi & Prosopis sp. & $\begin{array}{l}\text { USA, Texas, San Ygnacio, } \\
\text { bird sanctuary along } \\
\text { Rio Grande }\end{array}$ & KR-M-0006618 & MN072692 & - \\
\hline
\end{tabular}


Table 1 (continued)

\begin{tabular}{|c|c|c|c|c|c|}
\hline \multirow[t]{2}{*}{ Fungus } & \multirow[t]{2}{*}{ Host } & \multirow[t]{2}{*}{ Location } & \multirow[t]{2}{*}{ Voucher } & \multicolumn{2}{|c|}{ GenBank accession } \\
\hline & & & & $L S U$ & $\mathrm{CO} 3$ \\
\hline Ravenelia aff. indigoferae & Indigofera sp. & $\begin{array}{l}\text { South Africa, KwaZulu-Natal, } \\
\text { S } 27^{\circ} 28^{\prime} 32.9^{\prime \prime} \text {, E } 32^{\circ} 35^{\prime} 44.2^{\prime \prime}\end{array}$ & PREM61061 & MN072664 & MN095308 \\
\hline Ravenelia inornata & Vachellia natalitia & $\begin{array}{l}\text { South Africa, KwaZulu-Natal, } \\
\text { St. Lucia }\end{array}$ & KR-M-0006613 & MN072666 & - \\
\hline Ravenelia inornata & Vachellia karroo & $\begin{array}{l}\text { South Africa, Western Cape, } \\
\text { Entrance Montagu Nature } \\
\text { Reserve }\end{array}$ & PREM60135 & MN072684 & MN095310 \\
\hline Ravenelia inornata* & Vachellia karroo & $\begin{array}{l}\text { South Africa, Eastern Cape, } \\
\text { Kentani }\end{array}$ & PREM2368* & - & - \\
\hline Ravenelia inornata* & Vachellia karroo & $\begin{array}{l}\text { South Africa, Eastern Cape, } \\
\text { Kentani }\end{array}$ & PREM2541* & - & - \\
\hline Ravenelia inornata* & Vachellia karroo & $\begin{array}{l}\text { South Africa, Eastern Cape, } \\
\text { Somerset East }\end{array}$ & PREM20734*/** & - & - \\
\hline Ravenelia macowaniana & Vachellia natalitia & $\begin{array}{l}\text { South Africa, Limpopo, } \\
\text { Steelport, S } 24^{\circ} 41^{\prime} 32.3^{\prime \prime} \text {, } \\
\text { E } 30^{\circ} 12^{\prime} 32.3^{\prime \prime}\end{array}$ & PREM61862 & MG946012 & - \\
\hline Ravenelia macowaniana & Vachellia natalitia & $\begin{array}{l}\text { South Africa, Mpumalanga, } \\
\text { Nelspruit }\end{array}$ & PREM61218 & MG946011 & - \\
\hline Ravenelia macowaniana & Vachellia karroo & $\begin{array}{l}\text { South Africa, Limpopo, } \\
\text { Sekhukhuneland, } \\
\text { Winterveld Mine }\end{array}$ & PREM61222 & MG946007 & MN095331 \\
\hline Ravenelia macowaniana & Vachellia permixta & $\begin{array}{l}\text { South Africa, Limpopo, } \\
\quad \mathrm{S} 24^{\circ} 08^{\prime} 52.4^{\prime \prime}, \text { E } 29^{\circ} 02^{\prime} 21.9^{\prime \prime}\end{array}$ & PREM61875 & MG946014 & MN095327 \\
\hline Ravenelia macrocarpa & Senna subulata & $\begin{array}{l}\text { Argentina, Catamarca } \\
\text { Province, S } 28^{\circ} 03^{\prime} 44.1^{\prime \prime} \\
\text { W } 65^{\circ} 35^{\prime} 19.4^{\prime \prime}\end{array}$ & BPI841195 & DQ323926 & - \\
\hline Ravenelia mainsiana & Mimosa sp. & $\begin{array}{l}\text { Mexico, Veracruz Province, } \\
\text { N } 19^{\circ} 7^{\prime} 30.3^{\prime \prime}, \text { W } 96^{\circ} 50^{\prime} 07.1^{\prime \prime}\end{array}$ & BPI871923 & MN275525 & MN095302 \\
\hline Ravenelia mesilliana & Senna bicapsularis & $\begin{array}{l}\text { South Africa, Mpumalanga, } \\
\quad \mathrm{S} 25^{\circ} 02^{\prime} 38.1^{\prime \prime}, \text { E } 031^{\circ} 1^{\prime} 18.8^{\prime \prime}\end{array}$ & KR-M-0006424 & MN072693 & MN095334 \\
\hline $\begin{array}{l}\text { Ravenelia } \\
\quad \text { mimosae-sensitivae }\end{array}$ & Mimosa debilis & $\begin{array}{l}\text { Argentina, Salta Province, } \\
\text { between Rosario de la } \\
\text { Frontera and Horcones }\end{array}$ & BPI841052 & MN072650 & - \\
\hline Ravenelia minima* & Albizia gummifera & $\begin{array}{l}\text { South Africa, KwaZulu-Natal, } \\
\text { Durban }\end{array}$ & PREM30779 & - & - \\
\hline Ravenelia minima* & Albizia gummifera & South Africa, KwaZulu-Natal & PREM10697 & - & - \\
\hline Ravenelia modesta & Vachellia gerrardii & South Africa, SANBI & PREM61884 & MN072688 & - \\
\hline Ravenelia modesta & Vachellia gerrardii & $\begin{array}{l}\text { South Africa, Mpumalanga, } \\
\text { Barberton, S } 25^{\circ} 45^{\prime} 37.0^{\prime \prime} \text {, } \\
\text { E } 31^{\circ} 03^{\prime} 10.4^{\prime \prime}\end{array}$ & PREM61878 & MN072678 & - \\
\hline Ravenelia modesta & Vachellia rehmanniana & $\begin{array}{l}\text { South Africa, Limpopo, } \\
\text { Louis Trichard }\end{array}$ & PREM60991* & - & - \\
\hline Ravenelia modesta & Vachellia rehmanniana & $\begin{array}{l}\text { South Africa, Limpopo, } \\
\text { S } 23^{\circ} 57^{\prime} 40.3^{\prime \prime}, \text { E } 29^{\circ} 29^{\prime} 17.1^{\prime \prime}\end{array}$ & PREM60785* & - & - \\
\hline Ravenelia modesta & Vachellia rehmanniana & $\begin{array}{l}\text { South Africa, Limpopo, } \\
\text { S } 23^{\circ} 57^{\prime} 40.3^{\prime \prime}, \text { E } 29^{\circ} 29^{\prime} 17.1^{\prime \prime}\end{array}$ & PREM60791 & MN072660 & - \\
\hline Ravenelia modesta & Vachellia luederitzii var. retinens & South Africa, Gauteng & PREM60795 & MN072662 & MN095306 \\
\hline Ravenelia modesta & Vachellia luederitzii var. retinens & $\begin{array}{l}\text { South Africa, Gauteng, } \\
31 \text { miles North of Pretoria }\end{array}$ & PREM34572* & - & - \\
\hline Ravenelia modesta & Vachellia hebeclada & $\begin{array}{l}\text { South Africa, Gauteng, } \\
\text { Pienaars River }\end{array}$ & PREM30110*/** & - & - \\
\hline Ravenelia moloto & Senegalia erubescens & $\begin{array}{l}\text { South Africa, North-West } \\
\text { Province, Groot Marico }\end{array}$ & KR-M-0006445** & MN072697 & - \\
\hline Ravenelia moloto & Senegalia erubescens & $\begin{array}{l}\text { South Africa, North-West } \\
\text { Province, close to Madikwe }\end{array}$ & PREM61896** & MN072700 & MN095339 \\
\hline Ravenelia moloto & Senegalia erubescens & $\begin{array}{l}\text { South Africa, North-West } \\
\text { Province, close to Groot Marico }\end{array}$ & PREM61890** & MN072701 & MN095340 \\
\hline
\end{tabular}


Table 1 (continued)

\begin{tabular}{|c|c|c|c|c|c|}
\hline \multirow[t]{2}{*}{ Fungus } & \multirow[t]{2}{*}{ Host } & \multirow[t]{2}{*}{ Location } & \multirow[t]{2}{*}{ Voucher } & \multicolumn{2}{|c|}{ GenBank accession } \\
\hline & & & & $L S U$ & $\mathrm{CO} 3$ \\
\hline Ravenelia molopa & Senegalia galpinii & $\begin{array}{l}\text { South Africa, Mpumalanga, } \\
\text { Nelspruit, S } 28^{\circ} 29^{\prime} 50.5^{\prime \prime} \text {, } \\
\text { E } 30^{\circ} 59^{\prime} 27.3^{\prime \prime}\end{array}$ & PREM61879** & MN072679 & MN095323 \\
\hline Ravenelia modjadji & $\begin{array}{l}\text { S. polyacantha subsp. } \\
\text { campylacantha }\end{array}$ & $\begin{array}{l}\text { South Africa, Limpopo, } \\
\text { Louis Trichard }\end{array}$ & PREM61023** & MN072667 & MN095311 \\
\hline Ravenelia modjadji & $\begin{array}{l}\text { S. polyacantha subsp. } \\
\text { campylacantha }\end{array}$ & $\begin{array}{l}\text { South Africa, Limpopo, } \\
\text { Louis Trichard }\end{array}$ & KR-M-0006422** & MN072668 & MN095312 \\
\hline Ravenelia modjadji & $\begin{array}{l}\text { S. polyacantha subsp. } \\
\text { campylacantha }\end{array}$ & $\begin{array}{l}\text { South Africa, Limpopo, } \\
\qquad \mathrm{S} 23^{\circ} 37^{\prime} 55.1^{\prime \prime}, \text { E } 030^{\circ} 12^{\prime} 08.0^{\prime \prime}\end{array}$ & PREM60788** & MN072661 & MN095305 \\
\hline Ravenelia natalensis & Vachellia karroo & $\begin{array}{l}\text { South Africa, KwaZulu-Natal, } \\
\text { Winkelspruit }\end{array}$ & PREM2514* & - & - \\
\hline Ravenelia natalensis & Vachellia karroo & $\begin{array}{l}\text { South Africa, KwaZulu-Natal, } \\
\text { Winkelspruit }\end{array}$ & PREM1935*/** & - & - \\
\hline $\begin{array}{l}\text { Ravenelia } \\
\quad \text { neocaledoniensis }\end{array}$ & Vachellia farnesiana & $\begin{array}{l}\text { Australia, Northern Territory, } \\
\text { Timber Creek }\end{array}$ & BRIP56907 & KJ862347 & - \\
\hline $\begin{array}{l}\text { Ravenelia } \\
\quad \text { neocaledoniensis }\end{array}$ & Vachellia farnesiana & $\begin{array}{l}\text { Australia, Western Australia, } \\
\text { Kununurra }\end{array}$ & BRIP56908 & KJ862348 & KJ862460 \\
\hline Ravenelia ornata & Abrus laevigatus & $\begin{array}{l}\text { South Africa, Gauteng, Pretoria, } \\
\text { Botanical Garden }\end{array}$ & KR-M-0006447 & MN072687 & 一 \\
\hline Ravenelia ornata & Abrus sp. & $\begin{array}{l}\text { South Africa, Mpumalanga, } \\
\text { East of Nelspruit, Pullen Farm }\end{array}$ & KR-M-0006617 & MN072673 & MN095317 \\
\hline Ravenelia peglerae* & Senegalia caffra & $\begin{array}{l}\text { South Africa, Eastern Cape, } \\
\text { Kentani }\end{array}$ & PREM5626* & - & - \\
\hline Ravenelia peglerae* & Senegalia caffra & $\begin{array}{l}\text { South Africa, Eastern Cape, } \\
\text { Kentani }\end{array}$ & PREM2331*/** & - & - \\
\hline Ravenelia peglerae* & Senegalia caffra & $\begin{array}{l}\text { South Africa, Eastern Cape, } \\
\text { Butterworth }\end{array}$ & PREM2544*/** & - & - \\
\hline Ravenelia pienaarii* & Senegalia caffra & $\begin{array}{l}\text { South Africa, Gauteng, } \\
\text { Garstfontein }\end{array}$ & PREM6658*/** & - & - \\
\hline Ravenelia pienaarii* & Senegalia caffra & $\begin{array}{l}\text { South Africa, Gauteng, } \\
\text { Garstfontein }\end{array}$ & PREM5627*/** & - & - \\
\hline Ravenelia pienaarii & Senegalia caffra & $\begin{array}{l}\text { South Africa, Mpumalanga, } \\
\qquad \mathrm{S} 25^{\circ} 34^{\prime} 24.2^{\prime \prime} \text {, E } 31^{\circ} 10^{\prime} 51.7^{\prime \prime}\end{array}$ & KR-M-0045114 & MG954483 & - \\
\hline Ravenelia pienaarii & Senegalia caffra & $\begin{array}{l}\text { South Africa, Gauteng, } \\
\text { Ezemvelo Nature Reserve }\end{array}$ & KR-M-0006442 & MN072699 & MN095338 \\
\hline Ravenelia pienaarii & Senegalia caffra & $\begin{array}{l}\text { South Africa, Gauteng, } \\
\text { Ezemvelo Nature Reserve }\end{array}$ & PREM61892 & MG954482 & MN095337 \\
\hline Ravenelia piepenbringiae & Senegalia hayesii & $\begin{array}{l}\text { Panama, Chiriqí Province, } \\
\text { Los Algarrobos, N } 8^{\circ} 29^{\prime} 45.31^{\prime \prime} \text {, } \\
\text { W } 82^{\circ} 25^{\prime} 56.24^{\prime \prime}\end{array}$ & MP5157 & MG954489 & MN095328 \\
\hline Ravenelia platensis & Erythrina crista-galli & $\begin{array}{l}\text { Argentina, Buenos Aires } \\
\text { Province, La Plata }\end{array}$ & BPI841204 & MN072652 & MN095297 \\
\hline Ravenelia pretoriensis & Vachellia natalitia & $\begin{array}{l}\text { South Africa, KwaZulu-Natal, } \\
\text { Charters Creek }\end{array}$ & PREM61021 & MN072665 & MN095309 \\
\hline Ravenelia pretoriensis* & Vachellia karroo & $\begin{array}{l}\text { South Africa, Western Cape, } \\
\text { Jan Marais Nature Reserve }\end{array}$ & PREM60134* & - & - \\
\hline Ravenelia pretoriensis* & Acacia sp. & $\begin{array}{l}\text { South Africa, Gauteng, } \\
\text { Garstfontein }\end{array}$ & PREM1376**/* & - & - \\
\hline Ravenelia pretoriensis & Vachellia karroo & $\begin{array}{l}\text { South Africa, Gauteng, } \\
\text { Roodeplaat, ARC } \\
\text { Experimental Farm }\end{array}$ & PREM60809 & MN072659 & - \\
\hline Ravenelia pretoriensis & Vachellia karroo & $\begin{array}{l}\text { South Africa, Gauteng, } \\
\text { Roodeplaat, ARC } \\
\text { Experimental Farm }\end{array}$ & KR-M-0006615* & - & - \\
\hline Ravenelia sp. & Vachellia collinsii & $\begin{array}{l}\text { Costa Rica, Guanacaste Area } \\
\text { de Conservación Guanacaste }\end{array}$ & BPI872307 & MN326775 & 一 \\
\hline Ravenelia stictica & Mundulea sericea & South Africa, Gauteng, Pretoria & PREM60784 & MN072663 & MN095307 \\
\hline Ravenelia stictica & Mundulea sericea & $\begin{array}{l}\text { South Africa, Gauteng, Pretoria, } \\
\text { hill opposite to Freedom Park }\end{array}$ & ME138 & MN072658 & - \\
\hline
\end{tabular}


Table 1 (continued)

\begin{tabular}{|c|c|c|c|c|c|}
\hline \multirow[t]{2}{*}{ Fungus } & \multirow[t]{2}{*}{ Host } & \multirow[t]{2}{*}{ Location } & \multirow[t]{2}{*}{ Voucher } & \multicolumn{2}{|c|}{ GenBank accession } \\
\hline & & & & $L S U$ & $\mathrm{CO} 3$ \\
\hline Ravenelia stictica* & Mundulea sericea & South Africa, Limpopo, Mokopane & PREM28255* & - & - \\
\hline Ravenelia spinifera & Senegalia mellifera & $\begin{array}{l}\text { South Africa, Gauteng, } \\
\text { Ditholo Nature Reserve }\end{array}$ & KR-M-0006418** & MN072694 & - \\
\hline Ravenelia spinifera & Senegalia mellifera & $\begin{array}{l}\text { South Africa, Gauteng, } \\
\text { Ditholo Nature Reserve }\end{array}$ & KR-M-0006416** & MN072695 & MN09533 \\
\hline Ravenelia spinifera & Senegalia mellifera & $\begin{array}{l}\text { South Africa, Gauteng, } \\
\text { Ditholo Nature Reserve }\end{array}$ & KR-M-0006417** & MN072696 & MN095336 \\
\hline Ravenelia spinifera & Senegalia mellifera & $\begin{array}{l}\text { South Africa, North-West } \\
\text { Province, close to Madikwe }\end{array}$ & PREM61895** & MN072698 & - \\
\hline Ravenelia tephrosiae & Tephrosia praecana & $\begin{array}{l}\text { South Africa, Mpumalanga, } \\
\text { Komatipoort }\end{array}$ & PREM61003 & MN072670 & MN095315 \\
\hline Ravenelia tephrosiae & Tephrosia macropoda & $\begin{array}{l}\text { South Africa, KwaZulu-Natal, } \\
\text { Entumeni }\end{array}$ & PREM14190* & - & - \\
\hline Ravenelia tephrosiae & Tephrosia macropoda & $\begin{array}{l}\text { South Africa, KwaZulu-Natal, } \\
\text { Inanda }\end{array}$ & PREM10700* & - & - \\
\hline Ravenelia transvaalensis & Senegalia mellifera & $\begin{array}{l}\text { South Africa, North-West } \\
\text { Province, Pilanesberg }\end{array}$ & PREM61024 & MN072669 & MN095313 \\
\hline Ravenelia transvaalensis & Senegalia mellifera & $\begin{array}{l}\text { South Africa, North-West } \\
\text { Province; S } 25^{\circ} 29^{\prime} 44.3^{\prime \prime} \text {, } \\
\text { E } 26^{\circ} 23^{\prime} 57.0^{\prime \prime}\end{array}$ & PREM61858 & MG954485 & MN095318 \\
\hline Ravenelia transvaalensis & Senegalia mellifera & $\begin{array}{l}\text { South Africa, Gauteng, } \\
\text { Ditholo Nature Reserve }\end{array}$ & PREM61893 & MG954486 & - \\
\hline Ravenelia transvaalensis & Senegalia mellifera & South Africa, Gauteng & PREM27832* & - & - \\
\hline Ravenelia xanthophloeae & Vachellia xanthophloea & $\begin{array}{l}\text { South Africa, Mpumalanga, } \\
\mathrm{S} 25^{\circ} 26^{\prime} 10.0^{\prime \prime}, \text { E } 31^{\circ} 57^{\prime} 48.6^{\prime \prime}\end{array}$ & PREM61000** & MG946016 & MN095314 \\
\hline Ravenelia xanthophloeae & Vachellia xanthophloea & $\begin{array}{l}\text { South Africa, Mpumalanga, } \\
\text { S } 25^{\circ} 46^{\prime} 52.5^{\prime \prime} \text {, E } 31^{\circ} 03^{\prime} 10.7^{\prime \prime}\end{array}$ & PREM61215** & MG946017 & - \\
\hline Ravenelia xanthophloeae & Vachellia xanthophloea & $\begin{array}{l}\text { South Africa, KwaZulu-Natal, } \\
\text { S } 29^{\circ} 38^{\prime} 21.6^{\prime \prime} \text {, E } 31^{\circ} 05^{\prime} 27.3^{\prime \prime}\end{array}$ & PREM61213** & MG946015 & - \\
\hline Endoraecium tierneyi & Acacia harpophylla & Australia, Queensland, Tambo & BRIP27071 & KJ862335 & KJ862450 \\
\hline Endoraecium tropicum & Acacia tropica & $\begin{array}{l}\text { Australia, Northern Territory, } \\
\text { Gregory }\end{array}$ & BRIP56557 & KJ862337 & KJ862452 \\
\hline $\begin{array}{l}\text { Endoraecium } \\
\quad \text { violae-faustiae }\end{array}$ & Acacia difficilis & $\begin{array}{l}\text { Australia, Northern Territory, } \\
\text { Humpty Doo }\end{array}$ & BRIP56545 & KJ862344 & - \\
\hline
\end{tabular}

Sequences in bold were obtained in this study

*Specimens that were investigated only morphologically

**Type specimens used in this study

pretoriensis (PREM1376, PREM60134), R. stictica PREM28255), R. tephrosiae (PREM1419, PREM10700), and $R$. transvaalensis (PREM27832) were examined at the facilities of the ARC-Plant Protection Institute (ARC-PPRI), Roodeplaat, South Africa, using a Leica Dialux 22 EB microscope and a ColorView III CCD color camera, and measurements for these specimens were made using analySIS LS software (LS Research Software GmbH, Germany). Scanning electron microscopy (SEM) was done using a ZEISS Sigma VP scanning electron microscope. For this purpose, infected leaflets from the herbarium specimens were mounted on double-sided adhesive carbon tape on metal stubs and coated with gold in a sputter coater BAL-TEC SCD OSO (Capovani Brothers Inc., USA).

\section{DNA extraction and PCR}

The isolation of spores and DNA extraction procedures were carried out using the INNUPrep Plant DNA Kit (Analytik Jena, Jena, Germany) as described by Ebinghaus et al. (2018).

For PCR of the nc 28S rDNA (LSU), the Taq-DNAPolymerase Mix (PeqLab, Erlangen, Germany) and the GoTaq G2 HotStart DNA Polymerase Kit (Promega, Mannheim, Germany) were used, whereas only the GoTaq G2 HotStart DNA Polymerase Kit was used for PCR of CO3. To obtain sequences of the LSU, the primer pairs LR0R (Moncalvo et al. 1995) and LR6 (Vilgalys and Hester 1990) and 5.8SrustF/D1D2RustR (Ebinghaus et al. 2018) were used with the following conditions: 3 min at $96^{\circ} \mathrm{C}$ followed by 
40 cycles of $30 \mathrm{~s}$ at $95^{\circ} \mathrm{C}, 40 \mathrm{~s}$ at $49^{\circ} \mathrm{C}$, and $1 \mathrm{~min}$ at $72{ }^{\circ} \mathrm{C}$, final elongation was for $7 \mathrm{~min}$ at $72{ }^{\circ} \mathrm{C}$; for primers $5.8 \mathrm{SrustF} /$ D1D2rustF: 3 min at $96{ }^{\circ} \mathrm{C}$ followed by 40 cycles of $30 \mathrm{~s}$ at $96{ }^{\circ} \mathrm{C}, 45 \mathrm{~s}$ at $54^{\circ} \mathrm{C}$, and $1 \mathrm{~min} 20 \mathrm{~s}$ at $72{ }^{\circ} \mathrm{C}$, final elongation was for $7 \mathrm{~min}$ at $72{ }^{\circ} \mathrm{C}$. For amplification of $\mathrm{CO} 3$ sequences, the primer pair CO3-R1 and CO3-F1 (Vialle et al. 2009) was used with the following PCR conditions: initial denaturation for $3 \mathrm{~min}$ at $95{ }^{\circ} \mathrm{C}$ followed by 40 cycles of $95{ }^{\circ} \mathrm{C}$ for $50 \mathrm{~s}$, annealing at $45^{\circ} \mathrm{C}$ for $60 \mathrm{~s}$, and elongation at $72{ }^{\circ} \mathrm{C}$ for $60 \mathrm{~s}$. Final elongation was for $7 \mathrm{~min}$ at $72{ }^{\circ} \mathrm{C}$. The PCR products were purified using either Sephadex G-50 columns (SigmaAldrich, Steinheim, Germany) or ExoSAP-IT PCR Product Cleanup Reagent (Thermo Fisher Scientific GmbH, Schwerte, Germany). When only weak bands could be observed on agarose gels, PCR products were purified and concentrated using the Zymo Research DNA Clean \& Concentrator ${ }^{\mathrm{TM}}-5$ Kit (Zymo Research GmbH, Freiburg, Germany) following the manufacturer's protocol. DNA sequencing was carried out in both directions using the same primers as those used for PCR on a 3130XL Genetic Analyzer (Applied Biosystems) at the sequencing service of the Faculty of Chemistry and Biochemistry of the Ruhr University Bochum, Germany, or at GATC Biotech AG (Konstanz, Germany).

\section{Phylogenetic analyses}

Following successful sequencing, the sequences were screened against the NCBI GenBank using the BLASTn algorithm (Altschul et al. 1990) to check for erroneously amplified contaminations and to exclude them from further processing. Forward and reverse strands were then individually assembled and manually edited using Sequencher 5.0 software (Gene Codes Corp., Ann Arbor, MI, USA). A total of 91 DNA sequences were used to construct the alignments of the LSU and 49 sequences for the $\mathrm{CO} 3$ sequence data using MAFFT v7.154b (Katoh and Standley 2014) applying the L-INS-i strategy and edited manually. Missing data were coded as question marks in all alignments.

Maximum likelihood (ML) analyses were conducted in RAxMLGUI v.1.3 (Silvestro and Michalak 2012) using RaxML 8.0.26 (Stamatakis 2014) applying the general time reversible model of nucleotide substitution (Lanave et al. 1984) with gamma distributed substitution rates $(G T R+G)$. The analyses were run with a rapid bootstrap analysis using 1000 bootstrap replicates. The ML analyses were first conducted for each dataset separately and topological congruence was checked visually. Because no conflict of supported phylogenetic groupings was observed, a concatenated alignment was constructed for the LSU and $\mathrm{CO} 3$ sequence alignments and the subsequent phylogenetic analyses were inferred by applying the same methodology as for individual datasets.

Bayesian inference (BI) was performed with siMBa v.1.0 implemented in MrBayes 3.2.5 (Larget and Simon 1999;
Ronquist et al. 2012; Mishra and Thines 2014) applying the GTR $+\mathrm{G}$ substitution model. The Markov chain Monte Carlo search was run for five million generations with trees sampled every 500 generations. The burnin was set to 0.3. A Bayesian consensus tree was automatically calculated in siMBa and with posterior probabilities plotted on the tree. The phylogenetic trees of all different analyses were viewed and edited in FigTREE v1.4.0 (Rambaut 2009).

The taxonomic system proposed by Sydow (1921) for Ravenelia was applied. The respective generic names in addition to morphological and life cycle characteristics provided by literature were thus plotted on the phylogenetic reconstruction based on the LSU data.

\section{Results}

\section{Molecular phylogeny}

The LSU sequence data resulted in an alignment comprising 91 sequences of 1016 characters in total length with 436 variable positions of which 372 were parsimony informative, whereas the $\mathrm{CO} 3$ alignment comprised 49 sequences with a total length of 605 characters of which 183 were variable and 144 parsimony informative. All alignments are deposited at TreeBase (TB2:S24974, TB2:S24975, TB2:S24976).

The phylogenetic reconstructions of the LSU and $\mathrm{CO} 3$ sequence datasets resolved similar tree topologies. Slight differences can be observed in the topologies of both data sets, but only in the placement of weakly or unsupported groupings, e.g., clades II and IV (Fig. 1, 2 and 3, Fig. S1). No significantly different tree topologies were observed in ML and BI approaches for either dataset. We recognized seven clades (i.e., I-VII) that included at least one South African Ravenelia species (Fig. 1).

\section{Taxonomy}

The results of the present study, which includes molecular phylogenetic analyses and morphological investigations, led us to propose six taxonomic novelties described in the following section. In addition, four Ravenelia species are newly reported from South Africa, the species descriptions are emended for three rusts and a novel host report is included for one species.

Ravenelia moloto W. Maier, M. Ebinghaus, \& Begerow sp. nov. (Fig. 4a-g)

MycoBank MB831070

Etymology: Name refers to Moloto, which is the common name of the host tree Senegalia erubescens in the local Setswana language. 


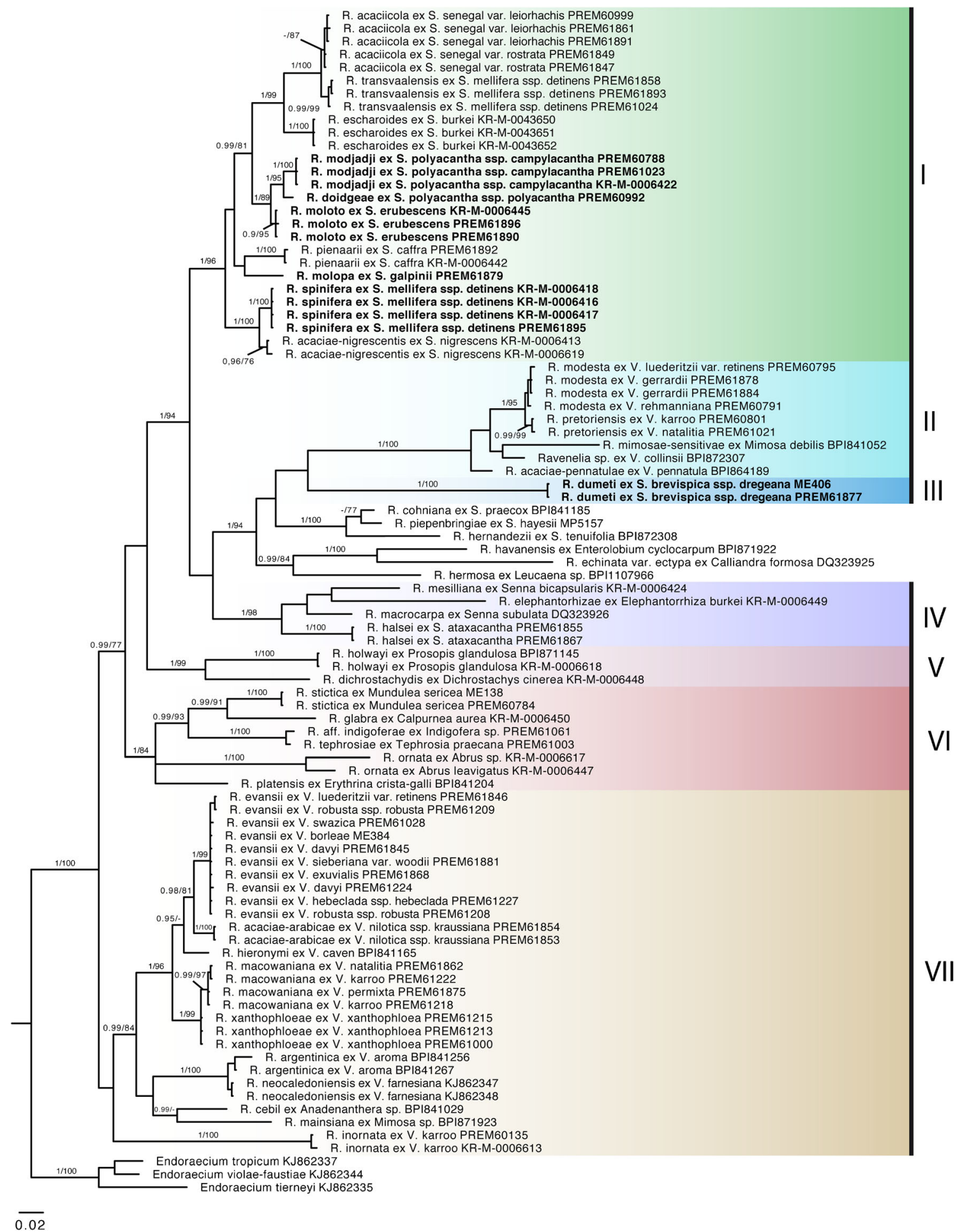

Fig. 1 Molecular phylogenetic reconstruction of the genus Ravenelia inferred from LSU sequences using BI. Posterior probabilities above 0.90 and MLbootstrap support above 75 are shown. Highlighted in bold are those species that were described as novel taxa in this study

Type: South Africa, North-West Province, Groot Marico, on leaves of S. erubescens (Welw. ex Oliv.) Kyal. \& Boatwr., 18 April 2009, W. Maier (WM3545), holotype KR-M-0006445.

Spermogonia and aecia not seen. Uredinia amphigenous but predominantly on the adaxial surface of the leaflets, sometimes on pods, sori on leaflets scattered or in small groups, shape ranging from circular to elongated, (60)120-250(460) $\mu \mathrm{m}$ in diameter, up to $6 \mathrm{~mm}$ in diameter when occurring on pods where sori form concentric eventually confluenting rings, subepidermal, erumpent; paraphyses 
Fig. 2 Cladogram based on a phylogenetic reconstruction using BI showing character states linked to species. Terminal branches were collapsed

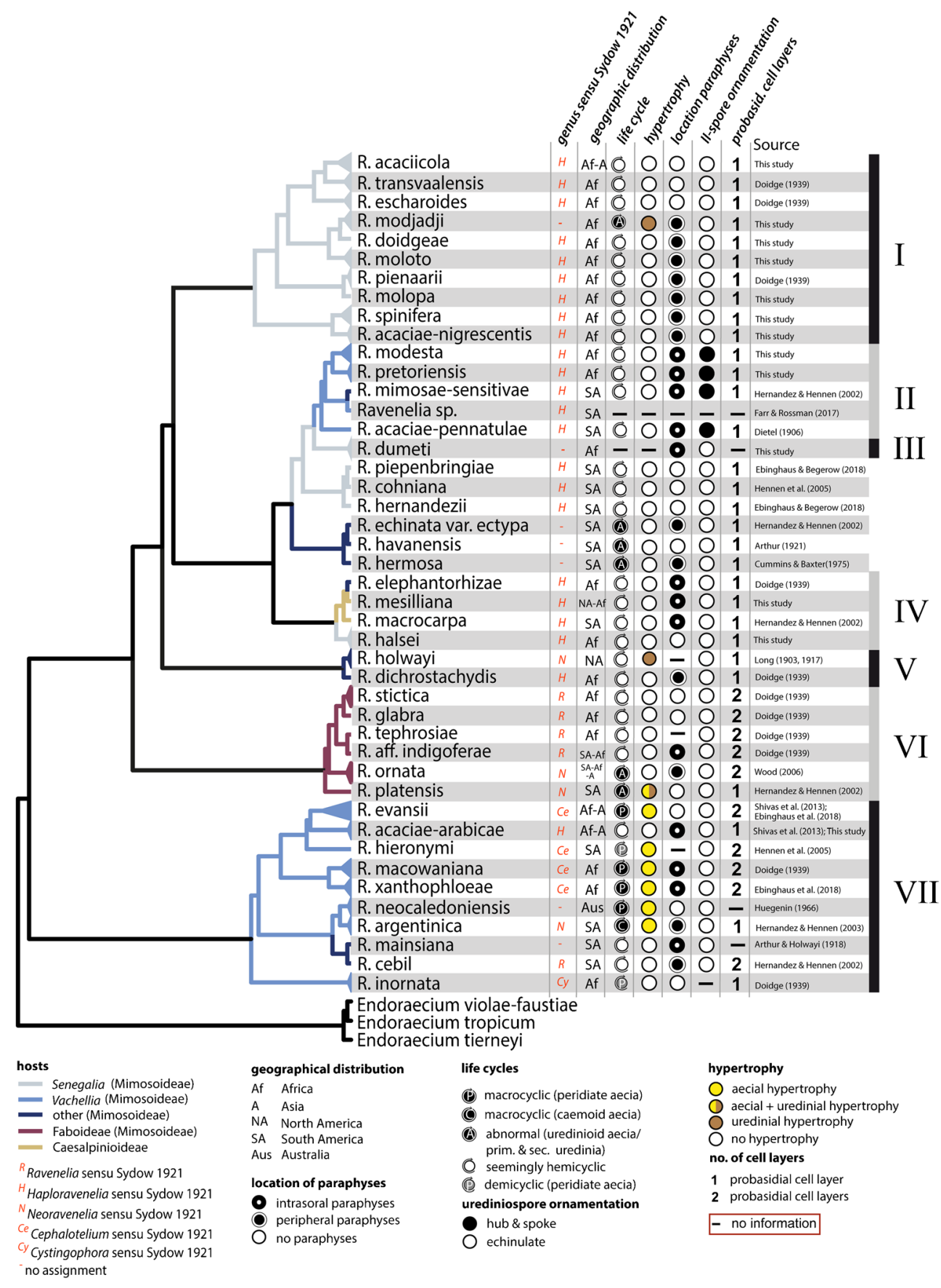

peripherically arranged within uredinia, cylindrical or sometimes clavate, often septate, $(27) 40-55(77) \times 6-13 \mu \mathrm{m}$, cell wall 1-1.7 $\mu \mathrm{m}$, transparent to light brown; urediniospores ovoidal to ellipsoidal, $12-16 \times 21-28 \mu \mathrm{m}$, spore wall evenly 1.4-2.2 $\mu \mathrm{m}$ thick, echinulate, aculei approximately $1 \mu \mathrm{m}$ in height, germ pores 5-6, equatorially arranged. Telia replacing uredinia, chestnut brown to dark brown; teliospores cinnamon brown to chestnut brown, circular to subcircular from above, (63)75-95(103) $\mu \mathrm{m}$ in diameter, upper side of the teliospores slightly convex to flattened, 5-7 probasidial cell across, probasidial cells $(20) 24-28(34) \times(12) 15-20(26) \mu \mathrm{m}$, cell wall thickened at the top side of the spore and here seemingly bilaminate with an inconspicuously thin, or sometimes distinctly marked hyaline to pale brown outer layer and a chestnut brown inner layer, the inner layer (1)3-5(7) $\mu \mathrm{m}$ thick, each cell with 7-13 verrucose ornamentations, $1-3 \mu \mathrm{m}$ in height; cysts pendent, globose, hyaline and smooth, in the same number as the probasidial cells, swelling in water but only slightly in lactophenol solution; pedicel multihyphal. 


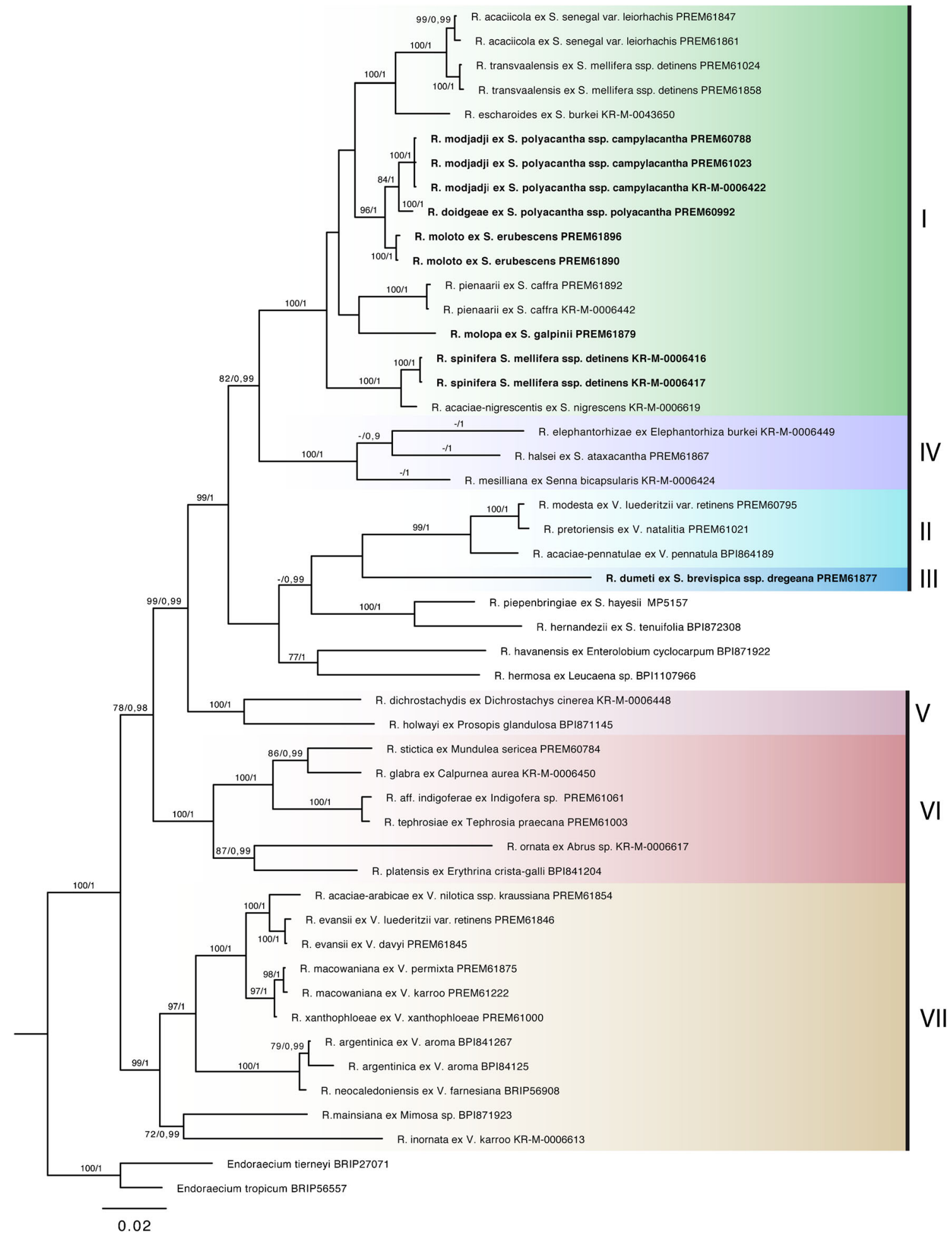

Fig. 3 Phylogenetic reconstruction based on a combined dataset of $C O 3$ and LSU sequence data. ML bootstrap values above 75 and $p$ values above 0.95 are shown. Species, described as novel taxa in this study, are highlighted in bold

Additional specimens examined: South Africa, North-West Province, on leaves of Senegalia erubescens, 16 April 2009, W. Maier (WM3554), paratypes PREM61896, KR-M0006443; close to Madikwe, 17 April 2009, W. Maier (WM3555), paratypes PREM61890, KR-M-0006415.
Notes: Ravenelia moloto was found to be closely related to $R$. modjadji on S. polyacantha subsp. campylacantha and to $R$. doidgeae found on S. polyacantha subsp. polyacantha but were clearly supported as distinct phylogenetic groups based on $\mathrm{LSU}$ and $\mathrm{CO} 3$ sequence data. 
Fig. 4 Ravenelia moloto. a Telia on leaflets of Senegalia erubescens. b SEM view of urediniospores showing germpores. c Lateral SEM view of teliospore showing the arrangement of sterile cysts. $\mathbf{d}$ SEM view of verrucose teliospore. e Single-septated paraphysis seen in LM. f LM of urediniospores showing equatorially arranged germpores. g Teliospore from top view by LM. Bars: $\mathbf{a}=0.2 \mathrm{~mm} ; \mathbf{b}=2 \mu \mathrm{m}$; $\mathbf{c}$ and $\mathbf{d}=10 \mu \mathrm{m} ; \mathbf{e}-\mathbf{f}=20 \mu \mathrm{m}$
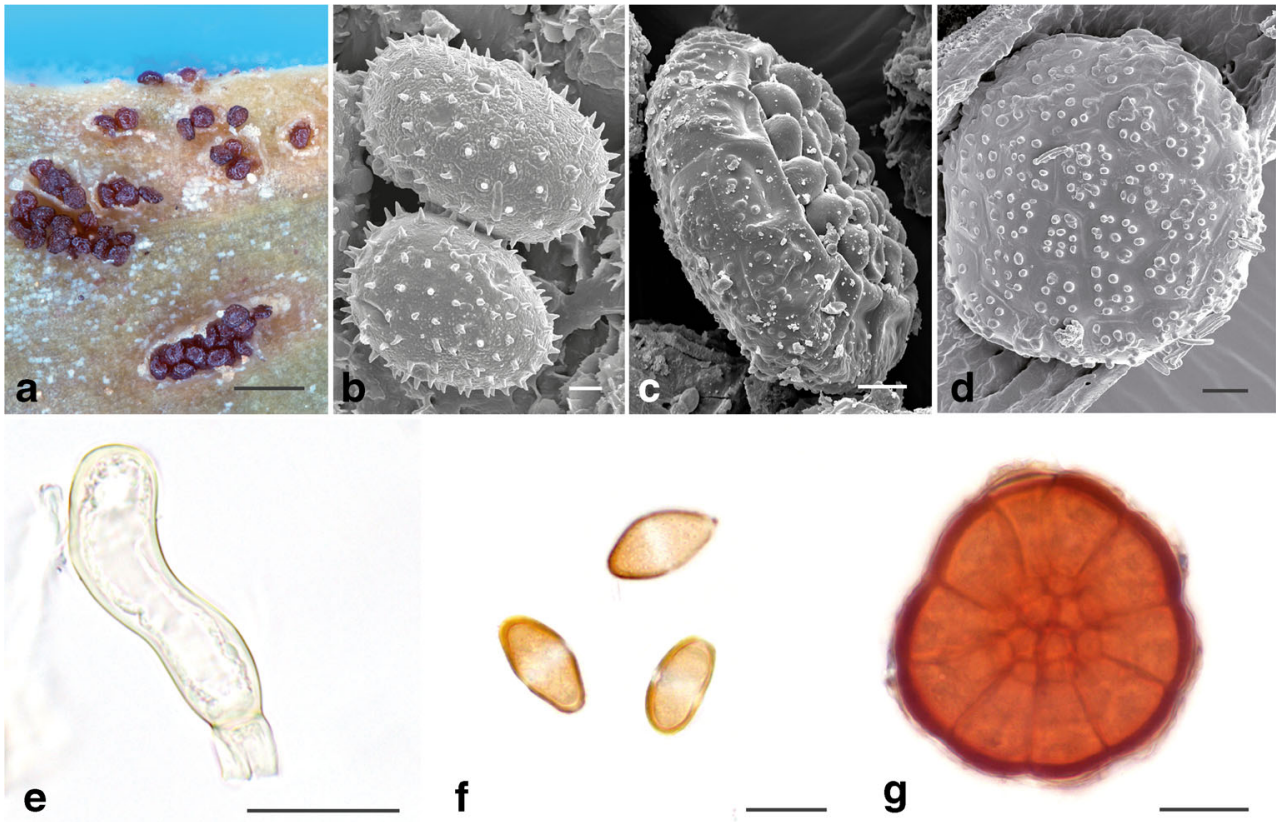

The close relationship between these species is reflected by their morphology that makes it difficult to distinguish between them. However, the teliospores of $R$. moloto tend to be smaller in diameter compared with those of $R$. doidgeae and its ornamentation often appears more pronounced. These two species show additional minor differences in urediniospore morphology as they often tend to be more globose in $R$. doidgeae. This rust has been found only on $S$. erubescens, a tree occurring in the dry savannah in the northeastern part of South Africa.
Ravenelia moloto might be restricted to this tree species in its natural environment.

Ravenelia spinifera W. Maier, M. Ebinghaus, \& Begerow sp. nov. (Fig. 5a-g)

MycoBank MB831071

Etymology: Name refers to the echinulate teliospores.

Type: South Africa, North-West Province, close to Madikwe, on leaves of Senegalia mellifera (Vahl) Seigel \&
Fig. 5 Ravenelia spinifera. a Telia on adaxial leaflet surface of S. mellifera. b Bottomside of a teliospore seen in LM. $\mathbf{c}$ Lateral view of teliospore seen in LM showing the hyaline sterile cysts. d LM from topside showing the compound teliospore with single probasidial cells. e-g SEM view of urediniospores. $\mathbf{f}$ Teliospores seen by SEM. Bars: $\mathbf{a}=0.2 \mathrm{~mm}$; $\mathbf{b}=20 \mu \mathrm{m} ; \mathbf{c}=25 \mu \mathrm{m} ; \mathbf{d}=$ $20 \mu \mathrm{m} ; \mathbf{e}=10 \mu \mathrm{m} ; \mathbf{f}=3 \mu \mathrm{m} ; \mathbf{g}=$ $10 \mu \mathrm{m}$
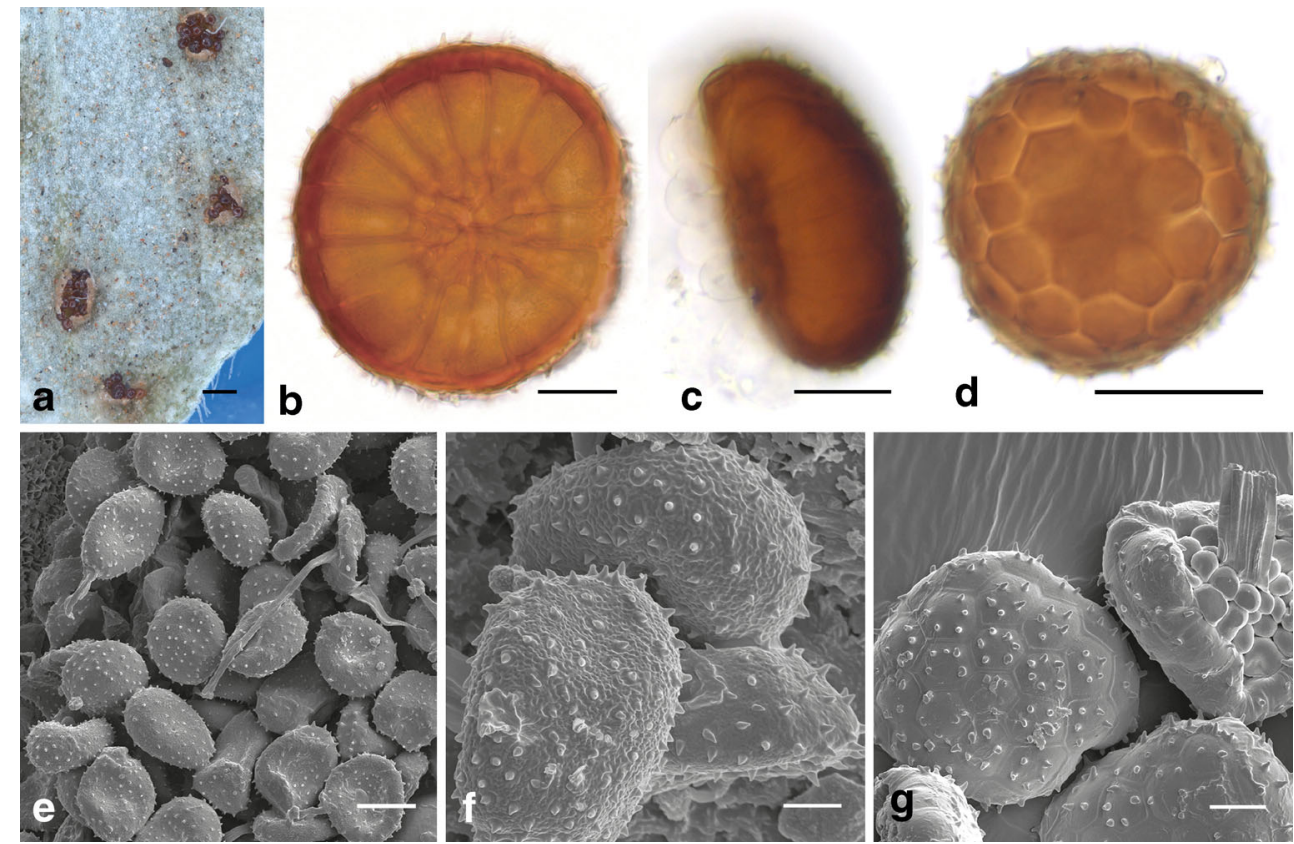
Ebinger subsp. detinens (Burch.) Kyal. \& Boatwr., 16 April 2009, W. Maier (WM3548), holotype PREM61895, isotype KR-M-0006412.

Spermogonia and aecia not seen. Uredinia amphigenous on leaflets, scattered or in loose groups, circular to elongated, 0.1-0.6 mm, subepidermal, erumpent. Urediniospores ovoidal to ellipsoidal, ochraceous brown, (13)16-22 × (11)13-16 $\mu \mathrm{m}$, spore wall evenly $1.5-2(2.5) \mu \mathrm{m}$ thick, often with attached pedicel, echinulate aculei short, less than $1 \mu \mathrm{m}$, distances between aculei about $1.5-2 \mu \mathrm{m}$, germ pores (4)5-6, in equatorial position; only few paraphyses observed in light microscopy, peripherally arranged, cylindrical to spathuliform, up to $65 \mu \mathrm{m}$ in length and $8 \mu \mathrm{m}$ in width, cell wall $1-1.5 \mu \mathrm{m}$, hyaline to subhyaline; telia replacing the uredinia, color ranging from cinnamon brown to dark brown; teliospores circular to subcircular from above, upper side of teliospores cinnamon brown to chestnut brown, convex to almost hemispherical, (64)75-95(111) $\mu \mathrm{m}$ in diameter with 5-8 probasidial cells across, probasidial cells (21)25-28(34) $\times(12) 15-19(24) \mu \mathrm{m}$, cell wall thickened at the top side and here seemingly bilaminate with a thin or inconspicious hyaline to pale brown outer layer and a chestnut brown inner layer, the inner layer (2) 4-5(7) $\mu \mathrm{m}$ thick, each probasidial cell bearing 4-7 spines, (2)3.5-4.5(6) $\mu \mathrm{m}$ long; cysts pendent, globose, hyaline, smooth, swelling in water but only slightly in lactophenol solution, number of cysts equal to the number of the probasidial cells; pedicel multihyphal, often persisting on detached spores.

Additional specimens examined: South Africa, Gauteng, Ditholo Nature Reserve, on leaves of S. mellifera subsp. detinens, 15 April 2009, W. Maier (WM3515), paratype KR-M-0006418; 15 April 2009, W. Maier (WM3516), paratype KR-M-0006416; 15 April 2009, W. Maier (WM3517), paratype KR-M-0006417.

Notes: Ravenelia spinifera is one of three species including $R$. transvaalensis and $R$. acaciae-melliferae occurring on Senegalia mellifera. While $R$. transvaalensis is also known from South Africa, Ravenelia acaciae-melliferae has been reported only from Eritrea and Ethiopia (Farr and Rossman 2017). Ravenelia spinifera can easily be distinguished from $R$. transvaalensis by its teliospores that have well-developed spines while those of $R$. transvaalensis are smooth-walled. Remarkably, we found host individuals with infections caused by both $R$. transvaalensis and $R$. spinifera even on a single leaflet. The original description of $R$. acaciae-melliferae is very limited and it does not provide details of teliospore ornamentation (Baccarini 1917). We thus consider the teliospores of that species as smooth and it remains uncertain whether $R$. acacia-melliferae species should be reduced to synonymy with $R$. transvaalensis. Ravenelia spinifera further resembles $R$. acaciae-nigrescentis on $S$. nigrescens in overall morphology. Nonetheless, both species were resolved in two wellsupported monophyla in phylogenetic reconstructions based on LSU and $\mathrm{CO} 3$ sequence data (Fig. 1 and 3). Additionally, $R$. spinifera appears to be restricted to $S$. mellifera subsp. detinens and the two species can thus also be distinguished by their host association.

Ravenelia molopa M. Ebinghaus, W. Maier, \& Begerow sp. nov. (Fig. 6a-g)

MycoBank MB831072

Etymology: Name refers to the occurrence of this rust fungus on Senegalia galpinii, which is known as Molopa in the local Northern Sotho language.
Fig. 6 Ravenelia molopa. a Uredinia on leaflets of $S$. galpinii. b Urediniospores and a singleseptated paraphysis seen in LM. c LM of a teliospore of $R$. molopa. d SEM view of a uredinium. Arrows indicate the peripherally arranged paraphyses. e

Urediniospores seen in SEM. $\mathbf{f}$ Bottomside of teliospores seen in SEM showing the arrangement of sterile cysts. Arrow indicates the multihyphal pedicel. g Teliospore from top view seen in SEM. Small verrucose ornamentations are more pronounced at the margins of the teliospore. Bars: $\mathbf{a}=$ $1 \mathrm{~mm} ; \mathbf{b}-\mathbf{d}=20 \mu \mathrm{m} ; \mathbf{e}=10 \mu \mathrm{m} ; \mathbf{f}$ and $\mathbf{g}=20 \mu \mathrm{m}$
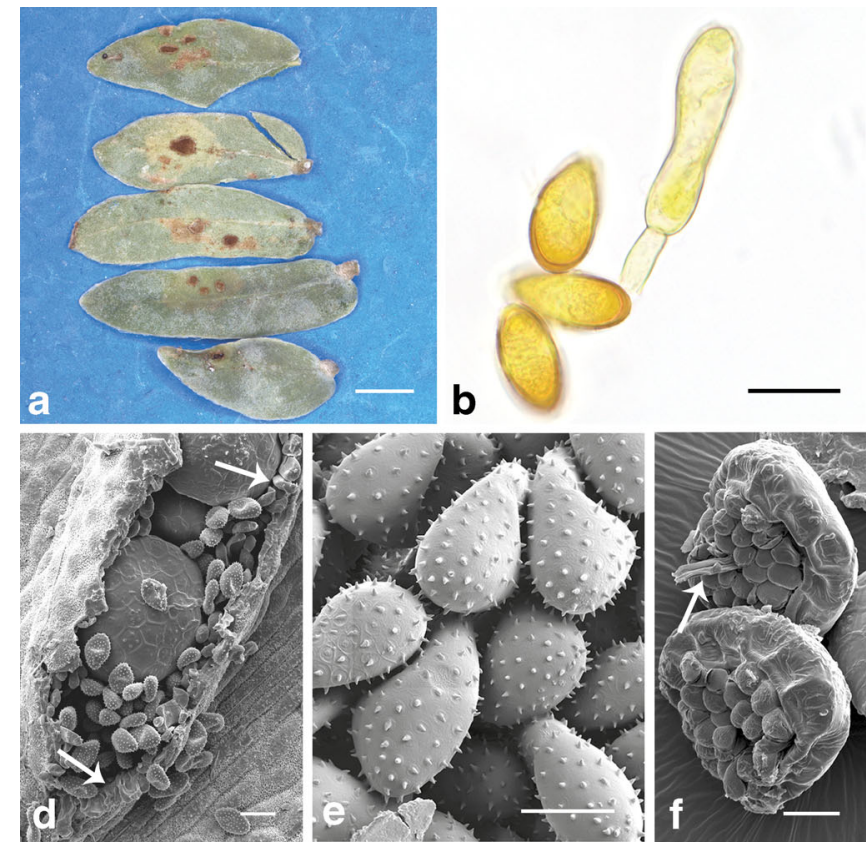
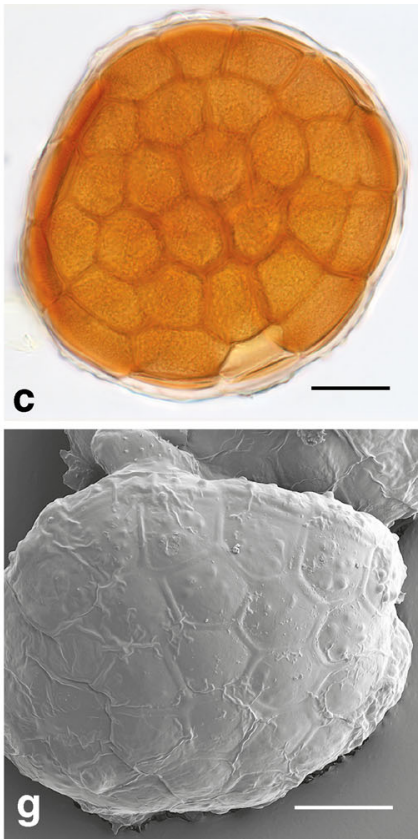
Type: South Africa, Mpumalanga, Nelspruit, S $28^{\circ} 29^{\prime}$ 50.5", E $30^{\circ} 59^{\prime} 27.3^{\prime \prime}$ on leaves of Senegalia galpinii (Burtt Davy) Seigler \& Ebinger, 16 February 2015, M. Ebinghaus (ME404), holotype PREM61879, isotype KR-M-0006614.

Spermogonia and aecia not seen. Uredinia amphigenous on leaflets, in small groups, subcircular to elongated, sometimes forming concentric rings, light brown, often surrounded by chlorotic areas, $0.1-0.6 \mathrm{~mm}$ in diameter, subepidermal, erumpent, peripheral paraphyses cylindrical and elongated to sometimes clavate, with a basal septum, 32-53 $\times 9-12 \mu \mathrm{m}$, cell wall thin and transparent $0.8-1.1(1.7) \mu \mathrm{m}$; urediniospores ovoidal to ellipsoidal, sometimes elongated, light brown (23)25-29(33) $\times$ $12-15 \mu \mathrm{m}$, spore wall laterally (1)1.3-1.6(2) $\mu \mathrm{m}$ thick, basally slightly thickened and apically often more pronounced thickened, echinulate, aculei approximately $1 \mu \mathrm{m}$ in height, germ pores $4-5$, equatorially arranged. Telia replacing the uredinia, orange brown to chestnut brown; teliospores orange brown to cinnamon brown, circular to subcircular from above, upper side of teliospores convex, (55)85-100(117) $\mu \mathrm{m}$ in diameter with 3-7 probasidial cells across, single probasidial cells (27)31-33(36) $\times(12) 14-18(25) \mu \mathrm{m}$, cell wall thickened at the top side of the spore and here distinctly bilaminate with a hyaline brown outer layer and a cinnamon brown inner layer, 3.5-6.5 $\mu \mathrm{m}$ thick, the peripheral cells each with 5-9 small verrucae, $1-1.5(2.5) \mu \mathrm{m}$, but central cells often smooth; cysts pendent, globose, hyaline and smooth, in the same number as the probasidial cells, swelling in water but only slightly in lactophenol solution; pedicel multihyphal.

Notes: This rust was found only once on a single tree in Nelspruit, Mpumalanga, in a private garden. The tree was most probably planted as an ornamental as this region is outside its natural distribution range that lies in the eastern part of the North-West Province, in western Limpopo and the northern parts of Gauteng and Mpumalanga (Coates Palgrave 2005; Smit 2008). The teliospores of $R$. molopa can easily be confused with those of $R$. pienaarii that infects the widely distributed $S$. caffra. However, the two species can be distinguished by the peripherally arranged paraphyses in the uredinia of $R$. molopa (Fig. 6d), while R. pienaarii is aparaphysate. These two rusts are also clearly separated by a significant genetic distance in molecular phylogenetic analyses of LSU and $\mathrm{CO} 3$ gene regions; however, the exact phylogenetic position of $R$. molopa within clade I could not be fully resolved (Figs. 1 and 3).

Ravenelia molopa can also be confused with R. escharoides, a rust species that infects $S$. burkei. However, the urediniospores and the teliospores of $R$. molopa are larger than those of $R$. escharoides and the sori of $R$. escharoides are aparaphysate.

Ravenelia doidgeae $\mathrm{M}$. Ebinghaus, Begerow, \& W. Maier sp. nov. (Fig. 7a-h)

MycoBank MB831073

Etymology: Name honors the South African Mycologist Ethel M. Doidge for her fundamental contributions to the knowledge on South African Ravenelia species.

Type: South Africa, Mpumalanga, Nelspruit, car park at the back entrance of the botanical garden, on leaves of Senegalia polyacantha subsp. polyacantha (Willd.) Seigler \& Ebinger, 10 April 2013, M. Ebinghaus (ME262), holotype PREM60992, isotype KR-M-0006612.

Spermogonia and aecia not seen. Uredinia amphigenous on leaflets, singly or in small groups, subcircular to elongated,
Fig. 7 Ravenelia doidgeae. a Telia on a leaflet of $S$. polyacantha subsp. polyacantha. b LM of urediniospores showing equatorially arranged germ pores. c Single-septated paraphysis seen in LM. d Teliospore of $R$. doidgeae seen in LM. e SEM view of an uredinium. $\mathbf{f}$ SEM view of an uredinium showing also peripherally arranged paraphyses and the torn epidermis. $\mathbf{g}$ Verrucose teliospores of $R$. doidgeae seen in SEM. $\mathbf{h}$ Bottomside of a teliospore seen in SEM showing sterile cysts. Bars: $\mathbf{a}=0.2 \mathrm{~mm} ; \mathbf{b}=20 \mu \mathrm{m} ; \mathbf{c}=$ $10 \mu \mathrm{m} ; \mathbf{d}-\mathbf{e}=20 \mu \mathrm{m} ; \mathbf{f}=10 \mu \mathrm{m}$; $\mathrm{g}=20 \mu \mathrm{m}$
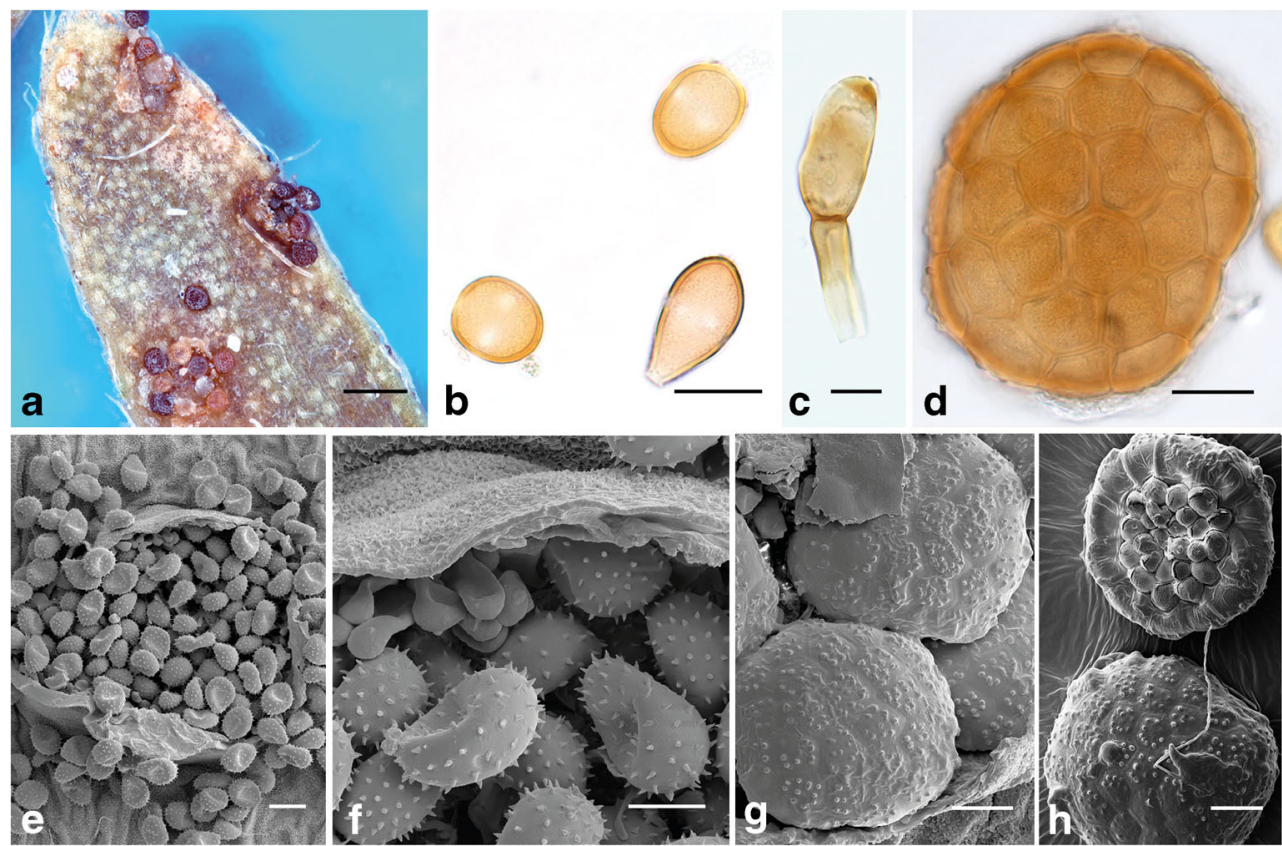
minute, $0.1-0.3 \mathrm{~mm}$ in diameter, light brown, subepidermal, erumpent; paraphyses peripheral, cylindrical to clavate, septated, with a distinctly thickened apical cell wall; ochraceous to light brown, total length $30-40 \mu \mathrm{m}$, upper cell $14-27 \times(5) 8-10 \mu \mathrm{m}$, lateral cell wall $1-1.5 \mu \mathrm{m}$ thick, at apex 1.5-3 $\mu \mathrm{m}$; urediniospores ovoidal to ellipsoidal, sometimes globose, light brown, (20)22-28(36) × 16-19 $\mu \mathrm{m}$, spore wall 1-1.5 $\mu \mathrm{m}$ thick, at the apex slightly thickened, echinulate, germ pores $4-7$, equatorially arranged; telia replacing the uredinia, chestnut to dark brown. Teliospores circular to subcircular from above, upper side of teliospores convex, orange brown to chestnut brown, (80)87-95(104) $\mu \mathrm{m}$ in diameter with 5-8 probasidial cells across, single probasidial cells (21) $24-28(33) \times(12) 14-18(22) \mu \mathrm{m}$, cell wall thickened at the top side of the spore and here bilaminate with a hyaline to pale brown outer layer that often seemingly get detached from a chestnut brown inner layer, the inner layer (2)4-6 $\mu \mathrm{m}$ thick, each cell bearing 8-13 verrucose ornamentations, (1)1.5-2.5(3) $\mu \mathrm{m}$ in height; cysts pendent, globose, hyaline, smooth, swelling in water but only slightly in lactophenol solution, number of cysts equal to the number of the probasidial cells; pedicel multihyphal.

Notes: Ravenelia doidgeae was found only once and the teliospores are morphologically difficult to discriminate from those of $R$. modjadji that can frequently be found on $S$. senegalia subsp. campylacantha. But the urediniospores of this rust tend to be more distinctly ovoidal than those of $R$. modjadji, which are more ellipsoid. Ravenelia doidgeae further resembles $R$. moloto in overall morphology but that rust has been found only on $S$. erubescens. Despite their morphological resemblance, the phylogenetic analyses of the LSU region resolved $R$. doidgeae as a distinct lineage in a close sister relationship to R. modjadji and R. moloto (Fig. 1).

Ravenelia modjadji M. Ebinghaus, W. Maier, \& Begerow sp. nov. (Fig. 8a-1)

MycoBank MB831074

Etymology: Name refers to the Rain Queen Modjadji of the Balobedu people that live in the region where the holotype specimen was collected.

Type: South Africa, Limpopo, near Modjadjiskloof, $\mathrm{S} 23^{\circ} 38^{\prime}$ 09.5", E $30^{\circ} 11^{\prime} 56.8^{\prime \prime}$, on malformed branches and leaves of Senegalia polyacantha (Willd.) Seigler \& Ebinger subsp. campylacantha (Hochst. ex. A. Rich.) Kyal. \& Boatwr., 21 February 2015, M. Ebinghaus (ME418), holotype PREM61860.

Spermogonia not seen. Primary uredinia typically on young shoots but sometimes expanding to leaves, causing malformations (e.g., "witches brooms"), developing singly but quickly growing confluently and then covering extended areas of infected shoots; primary urediniospores densely packed in sori, ochraceous brown, ellipsoidal, sometimes ovoidal, often somewhat curved, (23)25-28(32) × 10-12(14) $\mu \mathrm{m}$, spore wall $1-1.5(2) \mu \mathrm{m}$ thick, slightly thickened basally and at the apex, germ pores 4-5, equatorially arranged; uredinia predominatly on the adaxial side of leaflets, singly or in small groups, subcircular to ellipsoidal, light brown, minute, $0.1-0.4 \mathrm{~mm}$ in diameter; paraphyses peripheral, cylindrical to slightly clavate, sometimes bi- or trifurcate, with a single septum, transparent to light brown, thickened apex often more intensively colored, total length $42-55 \mu \mathrm{m}$, the upper cell $(14) 20-28(45) \times 6-10(13) \mu \mathrm{m}$, cell wall distinctly thickened apically, $3-9 \mu \mathrm{m}$ and $0.7-1.3 \mu \mathrm{m}$ laterally; urediniospores light brown, ovoidal to ellipsoidal or of irregular shape, (21)24-28(30) $\times(9) 12-14(16) \mu \mathrm{m}$, spore wall evenly (1) $1.3-1.5(2) \mu \mathrm{m}$ thick, germ pores $4-6$, equatorially arranged; telia replacing the uredinia, dark brown; teliospores subcircular from above, upper side of teliospores convex, orange brown to chestnut brown, (64)85-105(124) $\mu \mathrm{m}$ in diameter with 5-8 probasidial cells across, single probasidial cells (19) $25-29(36) \times(12) 15-19(30) \mu \mathrm{m}$, cell wall thickened at the top side of the spore and here bilaminate with a hyaline to pale brown outer layer that often seemingly get detached from a chestnut brown inner layer, the inner layer (2)4-6(8) $\mu \mathrm{m}$ thick, each cell with 8-14 verrucose ornamentations, $1-2(3) \mu \mathrm{m}$ in height; cysts pendent, globose, hyaline, smooth, swelling in water but only slightly in lactophenol solution, number of cysts equal to the number of the probasidial cells; pedicel multihyphal.

Additional specimens examined: South Africa, Limpopo, Louis Trichard, on leaves of Senegalia polyacantha subsp. campylacantha, 4 April 2013, M. Ebinghaus (ME240), paratype KR-M-0006422; 4 April 2013, M. Ebinghaus (ME239), paratype PREM61023; S $23^{\circ} 37^{\prime}$ 55.1", E $30^{\circ} 12^{\prime}$ 08.0", June 2013, M. Ebinghaus (ME182), paratype PREM60788.

Notes: Ravenelia modjadji is the only species within a monophyletic lineage of seemingly hemicyclic Senegalia rusts (clade I), which produces primary and secondary uredinia, and the primary uredinia causing malformations in its host. Similar to the gall-forming $R$. evansii and $R$. macowaniana, this spore stage is spatially separate from the (secondary) uredinia and telia. Old malformed branches often become detached from the trees during heavy rainfall or strong wind and can then be found in large abundance below the trees. $R$. modjadji can thus be easily distinguished from its close relatives, $R$. doidgeae and $R$. moloto if the aecia are present. It can also be differentiated based on the morphology of the urediniospores, which are ellipsoid in this Ravenelia while the latter two species have more ovoidal urediniospores. Ravenelia modjadji however shares a similar teliospore morphology with its phylogenetic close relatives $R$. doidgeae and $R$. moloto.

Ravenelia dumeti M. Ebinghaus, W. Maier, \& Begerow sp. nov. (Fig. 9a-h)

MycoBank MB831075

Etymology: The name is derived from the Latin word dumetum that describes a plant thicket and indicates the occurrence of the rust fungus in those habitats: the host 
Fig. 8 Ravenelia modjadji. a Malformed branches ("witches brooms") caused by the aecial state of $R$. modjadji on its host $S$. polyacantha subsp.

campylacantha. b LM of septated paraphyses. c Telia on leaflets. d Uredinia intermixed with teliospores. e Aeciospores seen in LM. $\mathbf{f}$ SEM view of an aecium. $\mathbf{g}$ SEM view of a uredinium showing paraphyses. $\mathbf{h}$ Teliospore seen in LM. i SEM view of aeciospores showing equatorial germ pores. $\mathbf{j}$ SEM view of a subepidermally erumpent telium. k Teliospores with verrucose ornamentations seen in SEM. 1 Bottomside of teliospore seen in SEM. Scale bars: $\mathbf{b}=20 \mu \mathrm{m} ; \mathbf{c}=$ $0.1 \mathrm{~mm} ; \mathbf{d}=0.5 \mathrm{~mm} ; \mathbf{e}=20 \mu \mathrm{m}$; $\mathbf{f}=30 \mu \mathrm{m} ; \mathbf{g}=10 \mu \mathrm{m} ; \mathbf{h}=20 \mu \mathrm{m}$; $\mathbf{i}=4 \mu \mathrm{m} ; \mathbf{j}=60 \mu \mathrm{m} ; \mathbf{k}$ and $\mathbf{l}=$ $20 \mu \mathrm{m}$
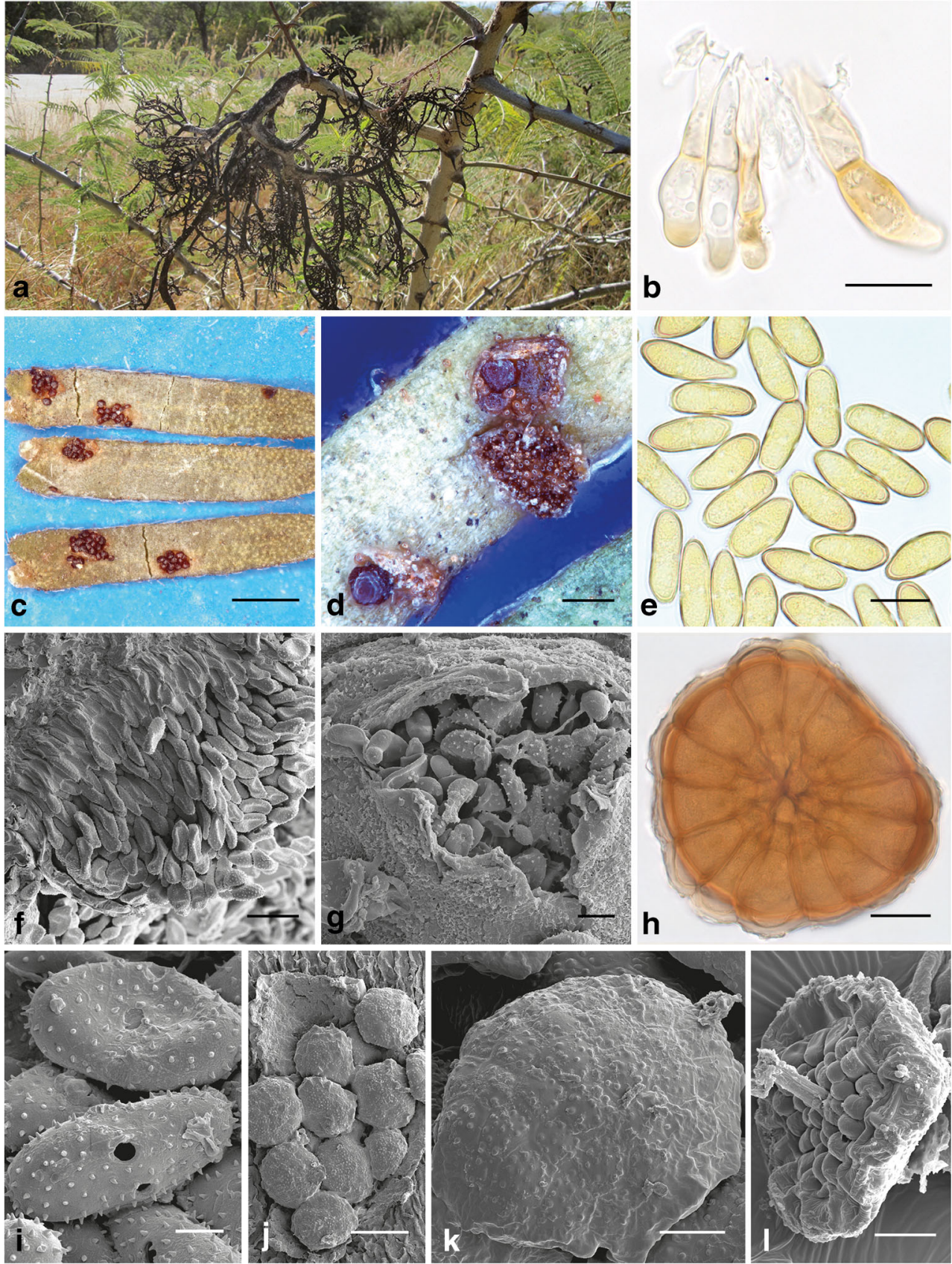

Senegalia brevispica forms dense and often impenetrable thickets at forest margins and along rivers in South Africa.

Type: South Africa, Mpumalanga, S $25^{\circ} 54^{\prime} 29.8^{\prime \prime}$, E $31^{\circ} 53^{\prime}$ 48.5", on leaves of Senegalia brevispica (Benth.) Kyal. \& Boatwr., 16 Feb. 2015, M. Ebinghaus (ME407), holotype PREM61877.

Spermogonia and aecia not seen. Uredinia predominantly on the abaxial side of the leaflets but also adaxially, irregularly arranged in small groups, circular to sometimes elongated, subcuticular, erumpent, ochraceous brown, minute, (50)100-150(240) $\mu \mathrm{m}$; paraphyses intrasoral, distinctly capitate, pedicel transparent and light brown at the thickened top, total length (22)24-29(35) $\mu \mathrm{m}$, capitulum 10-15 × (9)11-15 $\mu \mathrm{m}$, pedicel $3-5 \mu \mathrm{m}$ in width, cell wall laterally $1.1-1.5-1.8 \mu \mathrm{m}$ but apically thickened, (2)5-9 $\mu \mathrm{m}$; urediniospores broadly ovoidal, light ochraceous brown, echinulate, 12-16 ×9-12 $\mu \mathrm{m}$, spore wall evenly $1-1.5 \mu \mathrm{m}$, germ pores $4-6$, equatorially arranged.

Additional specimen examined: South Africa, Mpumalanga, S $25^{\circ} 54^{\prime} 29.8^{\prime \prime}$, E $31^{\circ} 53^{\prime} 48.5^{\prime \prime}$, on leaves of Senegalia brevispica, 16 Feb. 2015, M. Ebinghaus (ME406), paratype ME406. 
Fig. 9 Ravenelia dumeti. a Small groups of hypophyllous uredia on S. brevispica. b Section of an uredinium showing capitate paraphyses seen in LM. c-e Urediniospores showing equatorial germ pores (arrows) seen in LM. f SEM view of an uredinium. g SEM view of urediniospores intermixed with intrasoral paraphyses. h Detailed view of urediniospores seen in SEM including the torn cuticle. Scale bars: $\mathbf{a}=1 \mathrm{~mm} ; \mathbf{b}=20 \mu \mathrm{m}$; $\mathbf{c}-\mathbf{e}=10 \mu \mathrm{m} ; \mathbf{f}=20 \mu \mathrm{m} ; \mathbf{g}=$ $10 \mu \mathrm{m} ; \mathbf{h}=4 \mu \mathrm{m}$
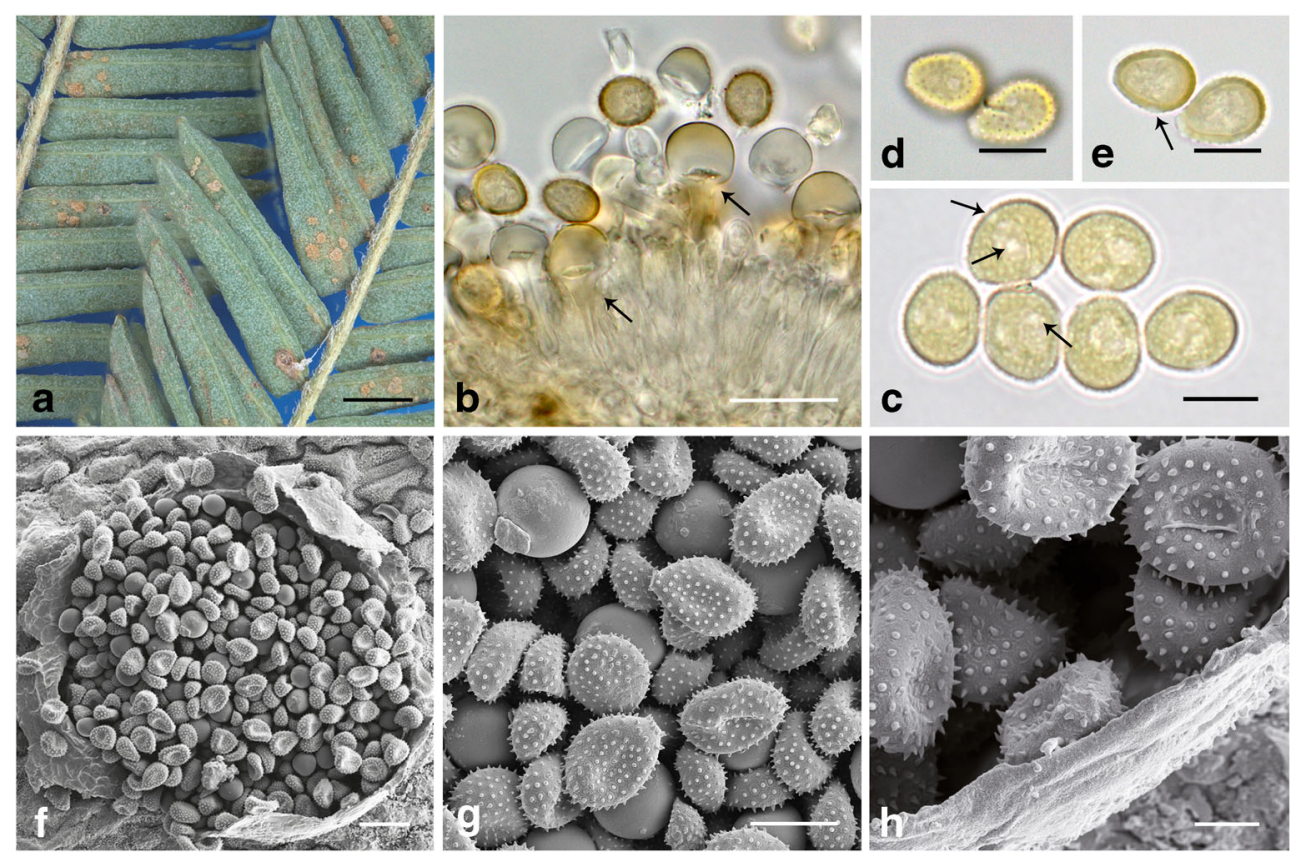

Notes: Only the uredinial stage is known for this species. Based on a close relationship to other Ravenelia species as well as its Senegalia host association, we have assigned this anamorphic rust to the genus Ravenelia. It is consequently the first rust fungus known to occur on S. brevispica. Unlike other Senegalia rusts in South Africa that occur in more open habitats, the host of this rust forms dense thickets along rivers and forest margins. This species clustered as a genetically distinct lineage when compared with other Ravenelia spp. infecting Senegalia hosts. The distinct phylogenetic position is also mirrored in its large and prominently capitate paraphyses that represent a rare feature in South African Ravenelias.

\section{New records for South Africa}

Ravenelia acaciae-arabicae Mundk. \& Thirum., Myc. Papers 16:17. 1946. (Fig. 10a-f)

Specimens examined: South Africa, S $30^{\circ} 01^{\prime} 07.2^{\prime \prime}$, E $30^{\circ}$ 13' 58.7", on leaves of Vachellia nilotica (L.) subsp. kraussiana (Benth.) P.J.H. Hurter \& Mabb., 2 February
Fig. 10 Ravenelia acaciaearabicae. a Infected leaflets of $V$. nilotica showing telia of $R$. acaciae-arabicae. $\mathbf{b}$ Urediniospores with germpores seen in SEM. c SEM view of teliospores showing verrucosa ornamentation on the topside and the arrangement of cysts on the bottomside. d Cylindrical paraphyses of $R$. acaciaearabicae seen in LM. e LM of urediniospores showing scattered germ pores. $f$ LM picture of a teliospore from bottom view. Scale bars: $\mathbf{a}=1 \mathrm{~mm} ; \mathbf{b}=10 \mu \mathrm{m}$; $\mathbf{c}=30 \mu \mathrm{m} ; \mathbf{d}-\mathbf{f}=20 \mu \mathrm{m}$
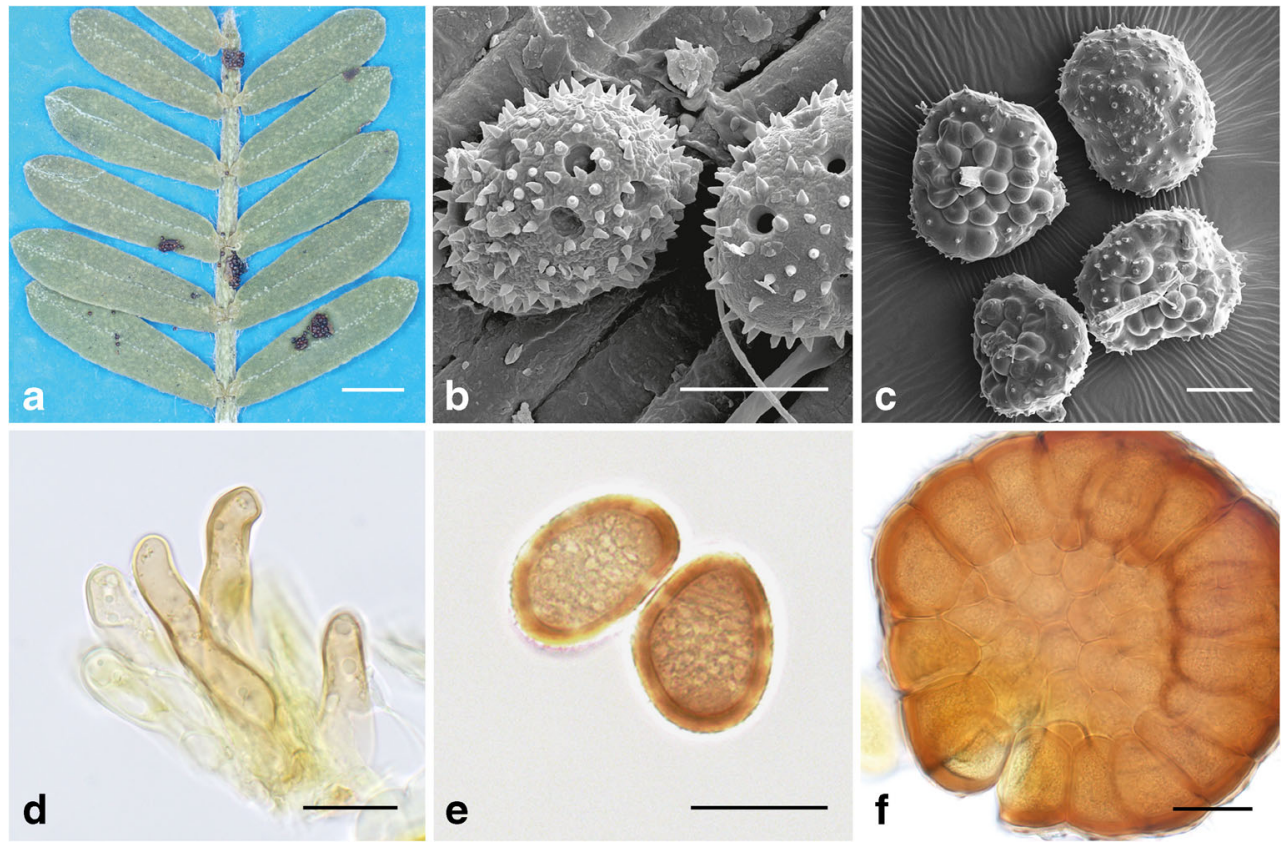
2015, M. Ebinghaus (ME374), PREM61854; KwaZuluNatal, S $29^{\circ} 49^{\prime} 29.1^{\prime \prime}$, E $30^{\circ} 32^{\prime}$ 08.5”, 4 February 2015, M. Ebinghaus (ME377), PREM61853; Weenen Nature Reserve, 13 March 2011, W. Maier (WM3674), KR-M-0006425; 13 March 2011, W. Maier (WM3675), KR-M-0006616.

Spermogonia and aecia not seen. Uredinia on the adaxial side of the leaflets and on rhachis, sori on leaflets subcircular to elongated, 150-390 $\mu \mathrm{m}$, sori on rhachis often larger, sometimes confluent, 790-1000 $\mu \mathrm{m}$, subepidermal, erumpent; paraphyses numerous, mostly peripheral but a few intrasoral, cylindrical, 46-54 ×6-8 $\mu \mathrm{m}$, light red-brown; urediniospores ovoidal to globose, ochraceous brown, 22-27 × 18-21 $\mu \mathrm{m}$, spore wall evenly (2)2.5-3 $\mu \mathrm{m}$ thick, verrucose, germ pores 8-12, scattered; telia replacing the uredinia, chestnut brown to dark brown; teliospores circular to subcircular in diameter and almost hemispherical at the top, chestnut brown to light brown, (62)80-99(110) $\mu \mathrm{m}$ in diameter with 5-6 probasidial cells across, few probasidial cells two-layered, single probasidial cells (18)23-28 ×(16)22-26(32) $\mu \mathrm{m}$, cell wall thickened at the top side of the spore and here seemingly bilaminate with a thin hyaline to pale brown outer layer and a chestnut brown inner layer, the inner layer (3)4-5(6) $\mu \mathrm{m}$, each cell with 6-9 blunt aculei, (1.5)3-5 $\mu \mathrm{m}$ in length; cysts pendent, globose, hyaline, smooth, swelling in water but only slightly in lactophenol solution, number of cysts equal to the number of the probasidial cells; pedicel multihyphal.

Notes: In 1946, this species was first described for India on Acacia arabicae Willd. (= Vachellia nilotica P.J.H. Hurter \& Mabb.) by Mundkur and Thirumalachar, and was recently more precisely reported on $V$. nilotica subsp. indica (Shivas et al. 2013). We report this rust for the first time on $V$. nilotica subsp. kraussiana that is widespread in southern Africa (Coates Palgrave 2005). Ravenelia acacia-arabicae is similar to $R$. tandoni that was described on Senegalia catechu (Sydow et al. 1937) but both species can be distinguished by predominantly hypophyllous uredinia in $R$. acacia-acaciae in contrast to the epiphyllous uredinia in $R$. tandonii. Furthermore, with $1-1.5 \mu \mathrm{m}$, the urediniospore wall of this rust is approximately half as thick as those of $R$. acaciae-arabicae, which is (2)2.5-3 $\mu \mathrm{m}$ thick. The urediniospores of the two rusts also differ in the number and arrangement of germ pores: 8-12 scattered germ pores in $R$. acaciae-arabicae compared with two rows of four germ pores in $R$. tandonii. The teliospores of Ravenelia acaciae-arabicae can be distinguished by having 6-9 blunt aculei per probasidial cell in contrast to 3-6 verrucose papillae in $R$. tandonii.

Phylogenetically, $R$. acaciae-arabicae is most closely related to $R$. evansii with which it shares major teliospore character traits such as size and its spinescent ornamentation. However, both species appear not to have a shared host range and can be thus easily distinguished based on their Vachellia hosts. Furthermore, R. evansii frequently causes aecial galls and malformations in infected host tissues while all collections of $R$. acaciae-arabicae in South Africa lack the aecial stage.

Ravenelia acaciicola (as acacicola) Sanwal, 1951. Sydowia 5: 414. (Fig. 11a-g)

Specimens examined: South Africa, KwaZulu-Natal, S $27^{\circ}$ $40^{\prime} 49.3^{\prime \prime}$, E $32^{\circ} 25^{\prime} 24.0^{\prime \prime}$, on leaves of Senegalia senegal (L.) Britton var. rostrata (Brenan) Kyal. \& Boatwr., 11 February 2015, M. Ebinghaus (ME389), PREM61849; S $27^{\circ}$ 29' 27.7",
Fig. 11 Ravenelia acaciicola. a Telia on a leaflet of $S$. senegal var. leiorhachis. b SEM view of telia showing smooth teliospores. c SEM view of teliospores showing topside and bottomside with sterile cysts. d SEM view of urediniospores of $R$. acaciicola. $\mathbf{e}$ LM of a teliospore in lateral view showing also hyaline cysts and the pedicel. $\mathbf{f} \mathrm{LM}$ of a teliospore from top view. $\mathrm{g}$ LM of urediniospores with the equatorially arranged germ pores. Scale bars: $\mathbf{a}=0.5 \mathrm{~mm} ; \mathbf{b}=$ $20 \mu \mathrm{m} ; \mathbf{c}=20 \mu \mathrm{m} ; \mathbf{d}=10 \mu \mathrm{m} ; \mathbf{e}-$ $\mathbf{g}=20 \mu \mathrm{m}$
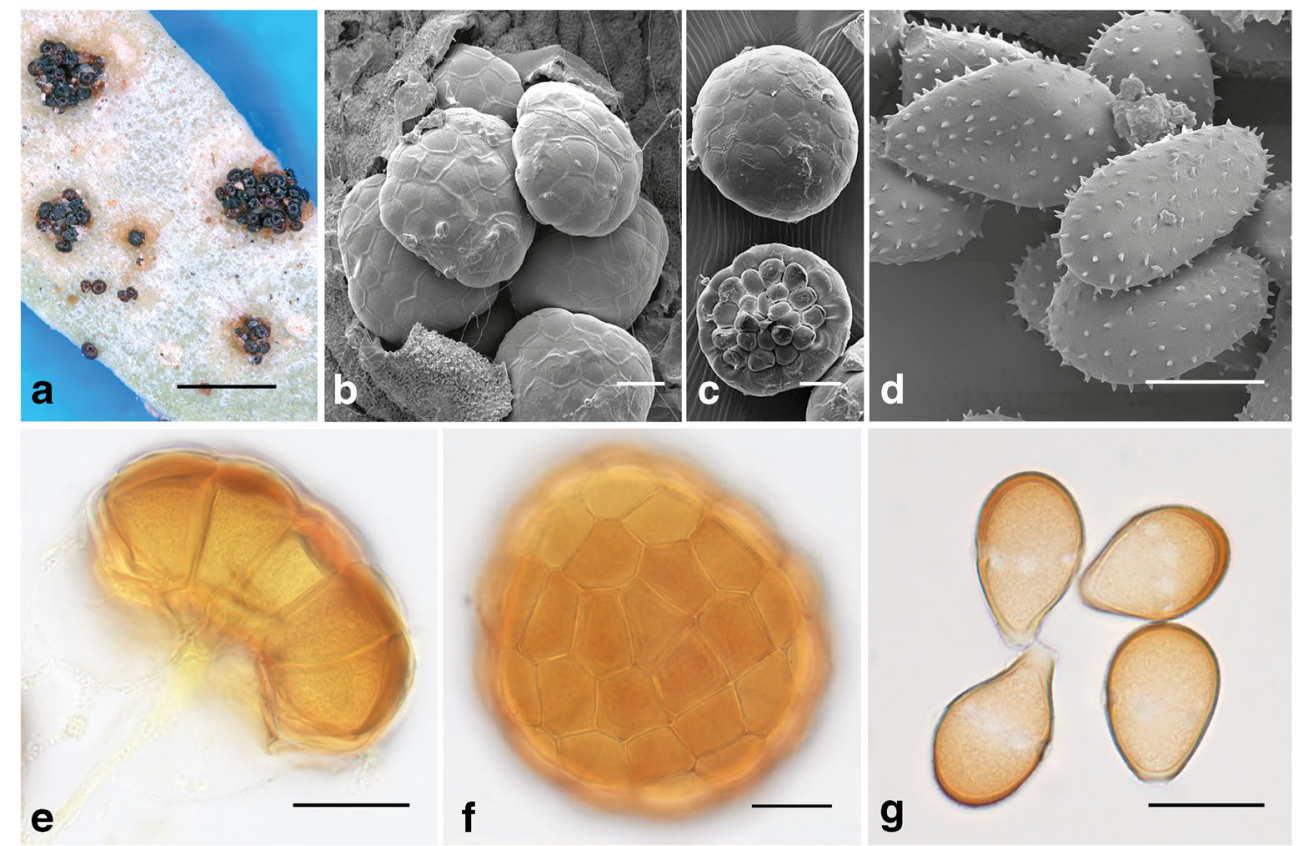

f

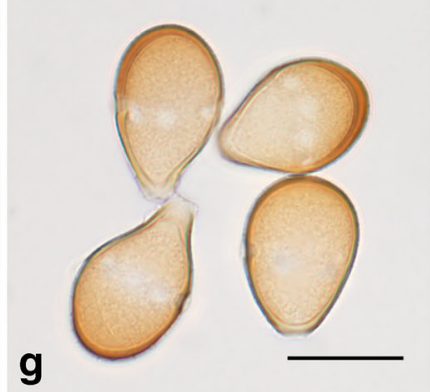


E $32^{\circ} 11^{\prime} 37.5^{\prime \prime}$, on leaves of $S$. senegal var. leiorhachis, 12 February 2015, M. Ebinghaus (ME392), PREM61847; Mpumalanga, Komatipoort, 9 April 2013, M. Ebinghaus (ME251), KR-M0006610; 9 April 2013, M. Ebinghaus (ME252), PREM60999; Limpopo, Steelport, S 24 44' 00.6", E $30^{\circ} 13^{\prime} 25.1^{\prime \prime}, 19$ February 2015, M. Ebinghaus (ME414), PREM61861.

Spermogonia and aecia not seen. Uredinia amphigenous on leaflets, circular to elongated, in small groups, brown, single sori minute, (120)180-300(400) $\mu \mathrm{m}$, subepidermal, erumpent; urediniospores ovoidal, often tapered towards the basis, ochraceous brown, echinulate, (24)28-33(38) $\times(13) 15-19(21) \mu \mathrm{m}$, spore wall thin but slightly thickened towards the apex and at the basis, $1-2(2.5) \mu \mathrm{m}$, germ pores $5-7$, equatorially arranged; paraphyses few, peripheral, capitate, about $45 \mu \mathrm{m}$ in length, capitulum approximately $14 \mu \mathrm{m}$ wide, light ochraceous brown; telia replacing the uredinia and therefore of same size and shape as the uredinia, dark brown to almost black; teliospores circular to subcircular in diameter, teliospores convex from above but with a concave bottomside, chestnut brown to light brown, (57)84-98(115) $\mu \mathrm{m}$ in diameter with $4-8$ probasidial cells across, single probasidial cells (15)27-32(35) × (13)16-19(28) $\mu \mathrm{m}$, cell wall thickened at the top side of the spore and here bilaminate with a hyaline outer layer and a chestnut brown inner layer, the inner layer (2)3-6(8) $\mu \mathrm{m}$, very rarely bearing single verrucose ornamentations of 1-2 $\mu \mathrm{m}$ in height; cysts pendent, globose, hyaline, smooth, swelling in water but only slightly in lactophenol solution, number of cysts equal to the number of the probasidial cells; pedicel multihyphal.

Notes: Ravenelia acaciicola was described by Sanwal (1951) in India on Acacia senegal Willd. (now Senegalia senegal (L.) Britton) without providing information regarding which of the four known subspecies of the tree was infected. Two varieties of $S$. senegal (var. leiorhachis and var. rostrata) occur in South Africa (Coates Palgrave 2005), both of which were found to be infected by $R$. acaciicola. Interestingly, we found some intraspecific genetic variability between specimens originating from the two different host varieties. Because these differences consisted of only one substitution each in the studied LSU and $\mathrm{CO} 3$ genes, we refrain from further splitting of $R$. acaciicola at this stage. However, it will be interesting to study additional specimens and gene regions for deeper insight.

The specimens examined in this study match the type descriptions given by Sanwal (1951) with respect to the size of the urediniospores as well as in the morphology of the teliospores. However, they differ in the number of germ pores in the urediniospores. Sanwal (1951) described four germ pores in an equatorial position, while 5-7 equatorial germ pores were observed in our collections. We also observed light brown and clavate paraphyses in a single specimen
(PREM61847) of S. senegal var. leiorhachis while Sanwal did not describe these structures. Considering the occurrence of this Ravenelia species on different subspecies of S. senegal, the observed morphological differences from type species could reflect phenotypic variability. Alternatively, cryptic species occur on the subspecies of the host tree. The mostly smooth teliospores of Ravenelia acaciicola resemble the closely related $R$. transvaalensis that infects $S$. mellifera in South Africa. But both rusts appeared to be host specific to $S$. senegal and S. mellifera subsp. detinens, respectively and were furthermore distinguished by phylogenetic analyses of the $\mathrm{LSU}$ and $\mathrm{CO} 3$ gene regions.

Ravenelia acaciae-nigrescentis Ritschel, Berndt, \& Oberw., Mycol. Progr. 6: 137. 2007 (Fig. 12a-g)

Specimens examined: South Africa, Mpumalanga, KNP, Orpen Camp; on leaves of Senegalia nigrescens (Oliv.) P.J.H. Hurter, 17 May 2004, W. Maier (WM3282), KR-M-0006413; Mpumalanga, KNP, Orpen Camp; on leaves of S. nigrescens, 14 May 2004, W. Maier (WM3278), KR-M-0006619.

Spermogonia and aecia not seen. Uredinia minute, 180-540 $\mu \mathrm{m}$, circular to elongated, subepidermal, erumpent; few peripheral paraphyses observed in light microscopy, cyclindrical to spathuliform, hyaline to subhyaline, up to $70 \mu \mathrm{m}$ in length and 6-8 $\mu \mathrm{m}$ in width, cell wall $1-1.5 \mu \mathrm{m}$; urediniospores ochraceous brown, subglobose to ovoidal, sometimes ellipsoidal, (15)17-20(23) $\times(11) 13-15 \mu \mathrm{m}$, spore wall evenly $1.5-2 \mu \mathrm{m}$, echinulate, $5-6$ equatorial germpores; telia predominantly on the abaxial side of leaflets, subepidermal, erumpent, circular to elongated, chestnut brown to dark brown, $180-540 \mu \mathrm{m}$; teliospores chestnut brown, circular to subcircular from above, upper side of teliospores convex, 85-107 $\mu \mathrm{m}$ in diameter, with $6-8$ probasidial cells across, single probasidial cell $26-30 \times 12-19 \mu \mathrm{m}$, cell wall thickened at the top side of the spore and here bilaminate with a hyaline outer layer and a chestnut brown inner layer, the inner layer 3-6 $\mu \mathrm{m}$, each probasidial cell bearing 4-6 spines, (1.8)4-6.2 $\mu \mathrm{m}$ in length; cysts pendent, hyaline, smooth, swelling in water but only slightly in lactophenol solution, number of cysts equal to the number of the probasidial cells; pedicel multihyphal.

Notes: The type specimen was collected in Namibia on Acacia nigrescens Oliv. (Ritschel et al. 2007) but its area of distribution is likely larger because the host tree is common throughout western and southern Africa (Coates Palgrave 2005). The original description lacks comments on the presence of paraphyses in R. acacia-nigrescentis. However, in the present study, a small number of peripherally arranged paraphyses were observed in light and scanning electron micrographs of the uredinia (Fig. 12g). This Ravenelia species resembles $R$. spinifera morphologically. The two species formed a highly supported monophyletic group representing two closely related but distinct sister species in our phylogenetic 
Fig. 12 Ravenelia acaciaenigrescentis. a Telia on the abaxial side of a leaflet of $S$. nigrescens. b LM of a teliospore from bottom view. c LM of a teliospore from top view. d LM of urediniospores. e Teliospores from top view seen in SEM. f SEM of teliospores seen in lateral view and from bottomside showing arrangement of cysts. g Urediniospores and paraphyses seen in SEM. Scale bars: $\mathbf{a}=2 \mathrm{~mm} ; \mathbf{b}, \mathbf{f}$, and $\mathbf{g}=$ $20 \mu \mathrm{m} ; \mathbf{c}=50 \mu \mathrm{m} ; \mathbf{d}=10 \mu \mathrm{m}$; $\mathbf{e}=40 \mu \mathrm{m}$
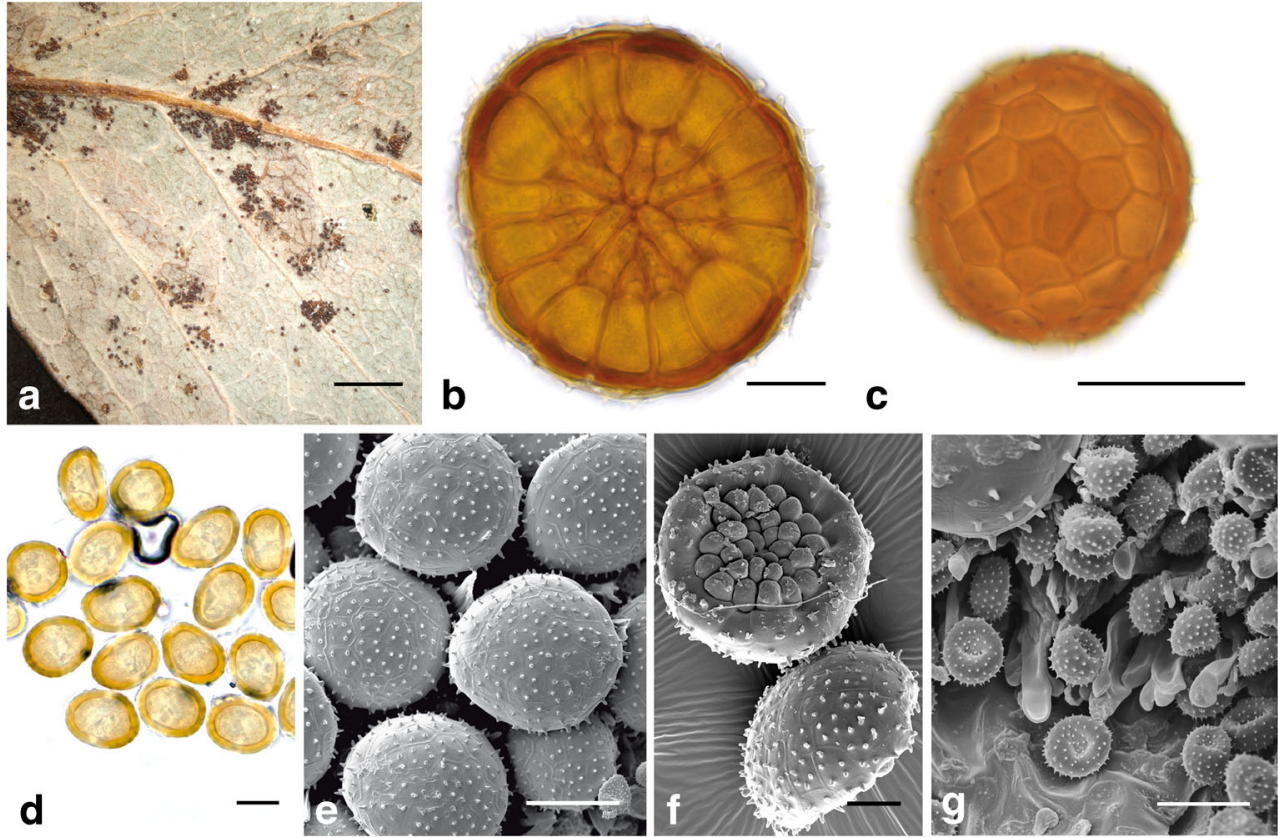

analyses (Figs. 1 and 3). Ravenelia acaciae-nigrescentis appeared host specific on $S$. nigrescens while $R$. spinifera was only found on S. mellifera.

Ravenelia mesilliana Ellis \& Barthol., Bull. Torrey Bot. Club 25: 508. 1898. (Fig. 13a-f

Specimen examined: South Africa, Mpumalanga, S $25^{\circ} 0^{\prime}$ 38.1", E $031^{\circ} 16^{\prime} 18.8^{\prime \prime}$, on leaves of Senna bicapsularis (L.) Roxb., 15 March 2006, W. Maier (WM3500), KR-M0006424 .

Fig. 13 Ravenelia mesilliana. a Uredinia forming concentric rings with chlorotic areas in its surrounding. b Uredinia intermixed with telia. c Teliospores in lateral view showing the multihyphal pedicel and hyaline cysts seen in LM. d SEM view of an uredinium with numerous intrasoral paraphyses. $\mathbf{e}$ Urediniospores and intrasoral paraphyses seen in SEM. f SEM view of the smooth teliospore showing pendent cysts and pedicel. Scale bars: $\mathbf{a}=1 \mathrm{~mm}$; $\mathbf{b}=0.2 \mathrm{~mm} ; \mathbf{c}=50 \mu \mathrm{m} ; \mathbf{d}=3 \mu \mathrm{m}$; $\mathbf{e}-\mathbf{f}=20 \mu \mathrm{m}$
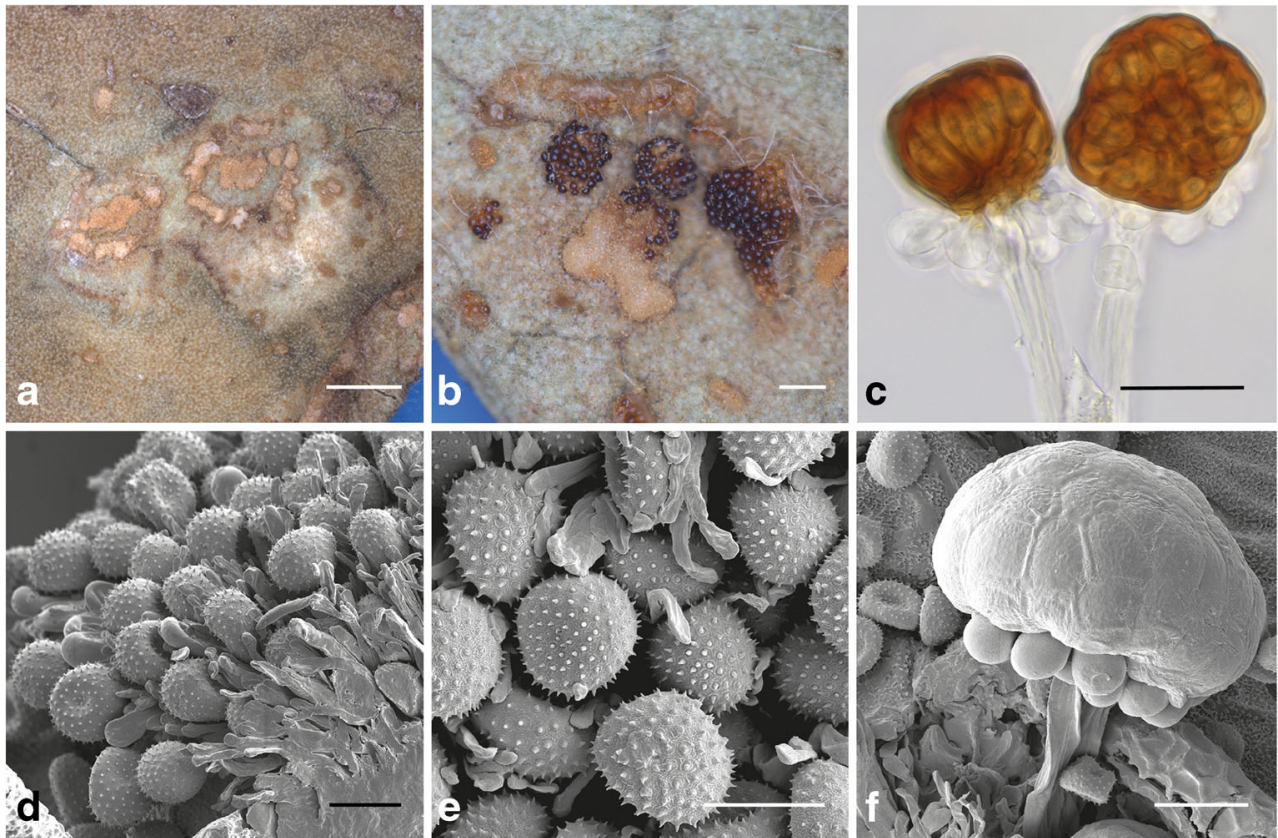
up to $40 \mu \mathrm{m}$ in length and 5-10 $\mu \mathrm{m}$ in width; urediniospores globose to rarely ovoidal, light ochraceous brown, echinulate, 14-18 $\mu \mathrm{m}$, spore wall evenly $1.5-2.5 \mu \mathrm{m}$, germpores 9-12, scattered; telia replacing the uredinia and therefore of same size and shape as the uredinia but also on rhachis, dark brown to blackish, teliospores circular in diameter and hemispherical in lateral view, chestnut brown to dark brown, (66)70-85(102) $\mu \mathrm{m}$ in diameter with 5-7 probasidial cells across, single probasidial cells (24)28-34(41) $\times(12) 15-19(25) \mu \mathrm{m}$, cell wall thickened at the top side of the spore and here with an inconspicuously thin outer hyaline to pale brown layer, (4) $5-7(9) \mu \mathrm{m}$, cell wall laterally (1.5)2-3(3.5) $\mu \mathrm{m}$ thick, probasidial cells rarely bear a single short and hyaline papillum up to $3.5 \mu \mathrm{m}$ in length; cysts pendent, globose, hyaline, smooth, easily detached, swelling in water but only slightly in lactophenol solution, number of cysts equal to number of probasidial cells. Pedicel sometimes light brown, up to $180 \mu \mathrm{m}$ in length, multihyphal.

Notes: There are a small number of records of Ravenelia arthuri Long occurring on Senna bicapsularis (L.) Roxb. in the Caribbean and Venezuela (Lenné 1990; Boa and Lenné 1994). Arthur described this rust in 1904 as $R$. portoricensis based on urediniospores occurring on Cassia emarginata L. (= Senna bicapsularis (L.) Roxb). The rust was later reduced to synonymy with $R$. arthuri (Long 1906) who also described the telial stage of this rust. Ravenelia mesilliana resembles the latter species in teliospore morphology but teliospores of $R$. arthuri are distinctly larger $(70-120 \mu \mathrm{m})$. Furthermore, the uredinia of $R$. arthuri were described as being subepidermal and mostly aparaphysate or having only few paraphyses. This is in contrast to R. mesilliana in which the sori originate subcuticularly and bear numerous intrasoral paraphyses of variable size and shape. Ravenelia mesilliana was originally described on Senna bauhinioides (Gray) Irwin \& Barneby. Consequently, Senna bicapsularis is a new host record for this rust fungus. Ravenelia mesilliana was most likely introduced into South Africa on Senna bicapsularis, which is an invasive species in this country (Foxcroft et al. 2003). Another rust, $R$. baumiana is known on Senna bicapsularis in Southern Africa (Angola) but it can be distinguished by its pronounced teliospore papillae (Doidge 1939), which were observed only rarely in R. mesilliana (Ellis and Everhart 1898, Baxter 1965).

\section{Emended species descriptions}

Ravenelia modesta Doidge, Bothalia 3: 504. 1939. emend. M. Ebinghaus, W. Maier \& Begerow (Fig. 14a-g)

Types: South Africa, Gauteng, 31 miles North of Pretoria, on leaves of $V$. gillettiae Burtt Davy (= Vachellia luederitzii var. retinens (Engl.) Kyal. \& Boatwr.), 21 March 1945, A.O.D. Mogg, syntype PREM34572; Gauteng, Pretoria, Botanical Garden, on leaves of $V$. luederitzii var. retinens, 24 June 2012, M. Ebinghaus (ME190), syntype PREM60795.
Spermogonia and aecia not seen. Uredinia amphigenous but predominantly hypophyllous, subcuticular, surrounded by the torn cuticle, subcircular, ochraceous brown, 0.1-0.2(0.3) mm; paraphyses intrasoral, capitate, ochraceous brown towards the thickened apex of the capitulum, total length (29)40-53 $\mu \mathrm{m}$, capitulum (10)12-14(16) $\mu \mathrm{m}$ in width, pedicel (2)4-6(7) $\mu \mathrm{m}$ in width, cell wall $1-1.5(2) \mu \mathrm{m}$ but apically thickened, 4-8 $\mu \mathrm{m}$; urediniospores ovoidal to ellipsoidal, light to ochraceous brown (17)20-23(27) $\times(13) 15-17(19) \mu \mathrm{m}$, spore wall slightly thickened towards the ends, (1)1.5-2(2.6) $\mu \mathrm{m}$, verrucose-echinulate, projections composed of a discus-like basis and a verrucose to echinulate apex, each projection connected by a distinct ridge, germ pores $8-12$, scattered or bizonate; telia replacing uredinia and therefore of same size and shape as the uredinia, dark brown, teliospores subcircular to circular from above and convex to hemispherical from side view, chestnut brown, (70)75-90(123) $\mu \mathrm{m}$ in diameter with (5)6-7(9) probasidial cells across, single probasidial cells (24)28-32(35) × (16)21-26(31) $\mu \mathrm{m}$, spore wall thickened at the top side of the spore and here bilaminate with a hyaline outer layer and a chestnut brown inner layer, the inner layer (3)4-5(6.5) $\mu \mathrm{m}$, each probasidial cell with 4-7 mostly blunt spines of (2)2.5-3.5(5) $\mu \mathrm{m}$ in length; cysts pendent, globose, hyaline, smooth, swelling in water but only slightly in lactophenol solution, number of cysts equal to number of the inner probasidial cells; pedicel multihyphal.

Additional specimens examined: South Africa, Limpopo, Polokwane Game Reserve; S $23^{\circ}$ 57' 40.3", E 29² 29' 17.1", on leaves of $V$. rehmanniana, 9 June 2012, M. Ebinghaus (ME181), paratypes PREM60785, KR-M-0006423; S 23 57' 40.3", E 29० 29' 17.1", 9 June 2012, M. Ebinghaus

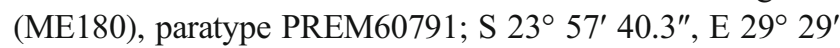
17.1", 9 June 2012, M. Ebinghaus (ME179), paratype PREM60792; Luis Trichard, 3 April 2013, M. Ebinghaus (ME233), paratypes PREM60991, KR-M-0006421; Mpumalanga, Nelspruit, Botanical Garden, on leaves of V. gerrardii, 21 June 2005, W. Maier (WM3425), paratypes PREM61884, K-M-0006426; Barberton, S $25^{\circ} 45^{\prime} 37.0^{\prime \prime}$, E $31^{\circ} 03^{\prime} 10.4^{\prime \prime}$, M. Ebinghaus (ME402), paratype PREM61878.

Notes: The type description of $R$. modesta (type: PREM30110, National Mycology Collections, Roodeplaat, South Africa) was based on telial rust infections found on Acacia stolonifera Burchell (Syn. for Vachellia hebeclada (D.C.) Kyal. \& Boatwr.) (Doidge 1939). Our comparisons of teliospore morphology with the phylogenetically distinct $R$. evansii (Sydow and Sydow 1912), however, aroused suspicion of conspecificity as they were largely the same. This is further supported by the fact that both rusts occur on $V$. hebeclada as we showed recently (Ebinghaus et al. 2018).

In 1948, Doidge added a description of the aecial and uredinial stage of $R$. modesta based on a specimen (PREM34572) collected from $V$. luederitzii (Doidge 1948) and which is also 
Fig. 14 Ravenelia modesta (a-g), $R$. pretoriensis $(\mathbf{h}-\mathbf{i})$, and $R$. halsei $(\mathbf{j}-\mathbf{l})$. a Uredinia on leaflets of Vachellia rehmanniana. b-c LM of urediniospores showing "hub and spoke" surface ornamentation (b) and scattered germ pores (c). d SEM of an uredinium of $R$. modesta with numerous intrasoral paraphyses. e SEM showing details of the "hub and spoke" surface ornamentation. Small spherical structures most likely represent brochosomes of insects. f Capitate paraphyses of $R$. modesta seen in LM. g SEM view of a spinescent teliospore. $\mathbf{h}$ Telium showing paraphyses and a verrucose to spinescent teliospore seen in SEM. $\mathbf{i}$ Teliospore seen in LM. $\mathbf{j}$ SEM view of a telium with few scattered urediniospores. $\mathbf{k}$ SEM view of teliospores. Arrows indicate verrucae on single probasidial cells. I Urediniospores seen in SEM. Scale bars: $\mathbf{a}=$ $0.5 \mathrm{~mm} ; \mathbf{b}-\mathbf{d}=20 \mu \mathrm{m} ; \mathbf{e}=1 \mu \mathrm{m}$; $\mathbf{f}-\mathbf{i}=20 \mu \mathrm{m} ; \mathbf{j}=50 \mu \mathrm{m} ; \mathbf{k}-\mathbf{l}=$ $10 \mu \mathrm{m}$
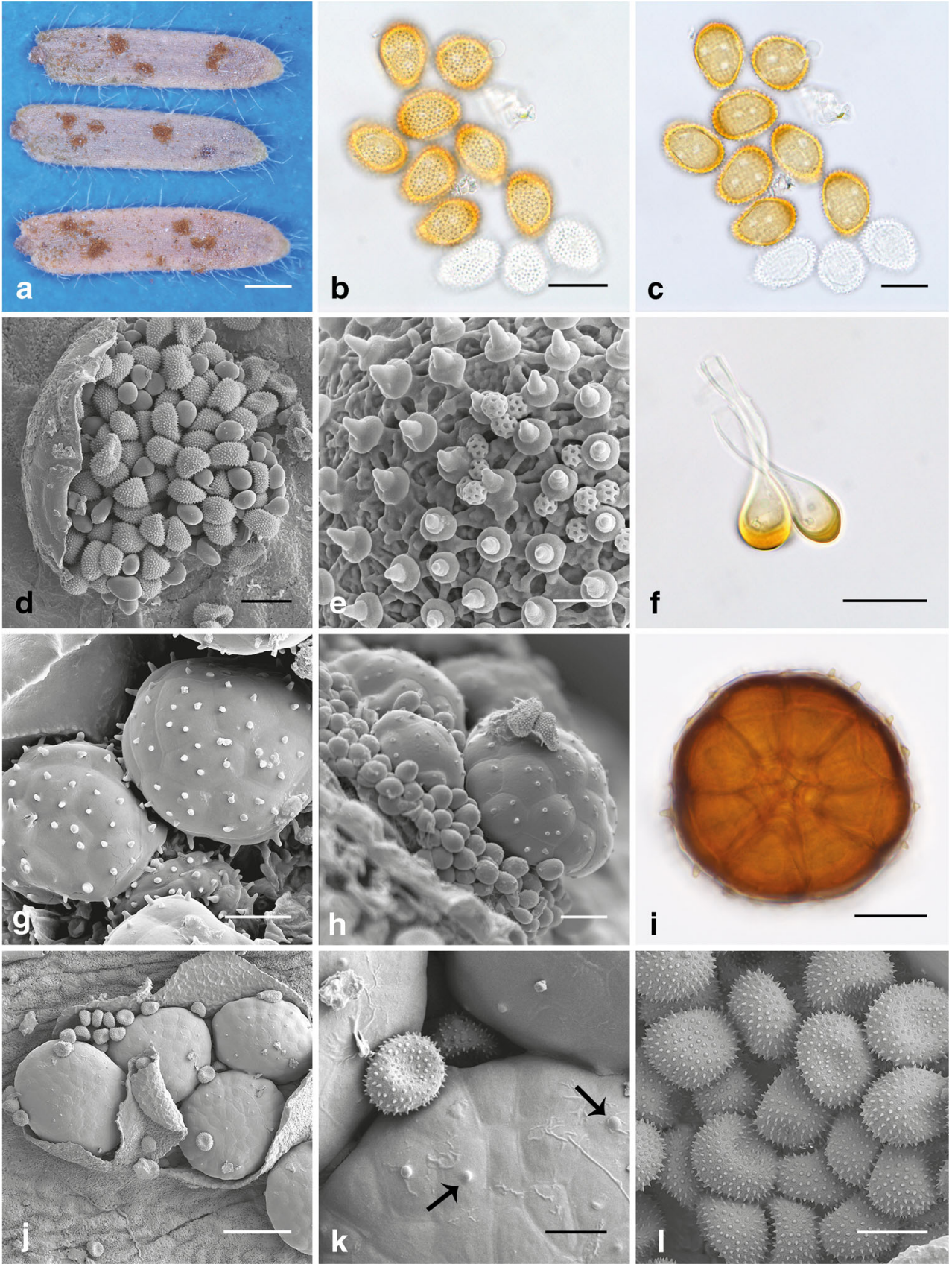

another common host of $R$. evansii (Ebinghaus et al. 2018). The urediniospores of this additional specimen of $R$. modesta were identical to the urediniospores of the specimens of $R$. modesta examined in our present study and these were clearly distinct from those of $R$. evansii. Based on our findings, we consequently consider the uredinial stage of this rust (PREM34572) as representing R. modesta Doidge.

However, it remains doubtful as to whether the aecial stage described by Doidge (1948) for this specimen is conspecific with the uredinia of $R$. modesta or whether the aecia actually represent $R$. evansii. We were unable to isolate DNA of sufficient quality from this specimen (PREM34572) and are thus unable to unequivocally confirm the assumed conspecificity of both spore stages with $R$. modesta. Nonetheless, because both rusts are able to infect the same host species, we propose (i) that the original description Doidge provided in 1939 for the telial stage of $R$. modesta is not correct but describes the teliospores of $R$. evansii and that $V$. hebeclada does not represent a host for $R$. modesta. (ii) The "connection" of the aecial stage with $R$. modesta given in Doidge (1948) is doubtful and may represent $R$. evansii as well. Ravenelia modesta Doidge should thus be re-typified with specimen PREM34572 collected on Vachellia luederitzii var. retinens (Engl.) Kyal. \& Boatwr. (syn. Acacia gillettiae Burtt Davy) for the uredinial 
stage and with PREM60795 on V. luederitzii var. retinens for the uredinial and telial stages. On the basis of our morphological as well as phylogenetic analyses we furthermore report Vachellia gerrardii and V. rehmanniana as new hosts for $R$. modesta and define the respective specimens as paratypes.

Ravenelia halsei Doidge, Bothalia 3: 504. 1939. emend. M. Ebinghaus. W. Maier, \& Begerow (Fig. 14j-1)

Types: South Africa, KwaZulu-Natal, Ndwedwe, on leaves of Senegalia ataxacantha, 26 July 1938, R. H. Halse, holotype PREM30117.

Spermogonia and aecia not seen. Uredinia amphigenous but predominantly hypophyllous, subcuticular, erumpent, singly or in small groups, circular to elongated or of irregular shape, covered by the bursting brownish cuticle when young, light ochraceous brown when older, often very minute, (40)60-210 $\mu \mathrm{m}$, aparaphysate; urediniospores broadly ovoidal to globose, transparent to light ochraceous brown, densely echinulate, $14-17 \times 12-14 \mu \mathrm{m}$, spore wall evenly $1.5-2 \mu \mathrm{m}$ thick, germ pores $13-15$, scattered; telia replacing uredinia and therefore of the same size and shape as uredinia, chestnut brown to dark brown; teliospores subcircular to circular in diameter and slightly convex at the upper side chestnut brown, 95-120 $\mu \mathrm{m}$ in diameter with $8-11$ probasidial cells across, single probasidial cells $20-24(28) \times(9) 11-14(20) \mu \mathrm{m}$, cell wall thickened at the top side of the spore, (2)3-5(6) $\mu \mathrm{m}$, few cells bearing a single short papillum of (1)2-2.5(3) $\mu \mathrm{m}$ in height; cysts pendent, globose, hyaline, smooth, swelling in water but only slightly in lactophenol solution, number of cysts equal to the number of the probasidial cells; pedicel multihyphal.

Additional specimens examined: South Africa, Mpumalanga, S $25^{\circ} 02^{\prime} 33.4^{\prime \prime}$, E31 ${ }^{\circ} 06^{\prime} 10.3^{\prime \prime}$, on leaves of S. ataxacantha, 18 Feb. 2015, M. Ebinghaus (ME411), paratype PREM61867; Nelspruit, Botanical Garden, 22 June 2009, W. Maier (WM3424), paratype KR-M-0006620.

Notes: The type material used by Doidge for the type description of $R$. halsei (PREM30117) lacks the uredinial stage (Doidge 1939). Specimens collected in recent years showed uredinial infections (PREM61867, KR-M-0006620) and we have, therefore, presented detailed descriptions of the uredinial stage of $R$. halsei. Additionally, scanning electron microscopy (SEM) revealed the presence of verrucae on few teliospores of the investigated specimens that were described.

Ravenelia pretoriensis Syd \& P. Syd, Annls Mycol. 10: 441. 1912. emend. M. Ebinghaus, Begerow, \& W. Maier (Fig. 14h-i)

Types: South Africa, Gauteng, Garstfontein, on leaves of Acacia horrida Willd., 11 April 1911, E.M. Doidge, holotype PREM1376.

Spermogonia and aecia not seen. Uredinia amphigenous, subcuticlar, circular to elongated, surrounded by the torn cuticle, light brown, minute 70-250 $\mu \mathrm{m}$; paraphyses intrasoral, capitate, only few appearing clavate, ochraceous brown towards the thickened apex of the capitulum, 34-53 $\mu \mathrm{m}$ in total length, capitulum (5)9-13 $\mu \mathrm{m}$ in width with a thickened apex of 4-9 $\mu \mathrm{m}$, pedicel $3-5 \mu \mathrm{m}$ in width, cell wall $1-2 \mu \mathrm{m}$ thick; urediniospores ovoidal to ellipsoidal, light ochraceous brown, 19-23 $\times 14-17 \mu \mathrm{m}$, spore wall (1)1.5-2 $\mu \mathrm{m}$ and slightly thickened towards the apex, verrucose-echinulate, projections composed of a discus-like basis and a verrucose to echinulate apex, each projection connected by a distinct ridge, germ pores (8)10-12, scattered or bizonate; telia replacing uredinia and therefore of same size and shape as the uredinia, chestnut brown to dark brown, teliospores subcircular to circular from above, upper side of teliospores convex to hemispherical, chestnut brown to dark brown, (60)70-95(105) $\mu \mathrm{m}$ in diameter with 5-7 probasidial cells across, single probasidial cells (20)25-30(36) $\times(14) 17-22(29) \mu \mathrm{m}$, cell wall thickened at the top side of the spore and here bilaminate with a hyaline outer layer and a chestnut brown to dark brown inner layer, the inner layer, (2)3-5(6) $\mu \mathrm{m}$, each probasidial cell with 4-7 papillae of (1)2-3(4) $\mu \mathrm{m}$ in length; cysts pendent, globose, hyaline, smooth, swelling in water but only slightly in lactophenol solution, number of cysts equal to the number of the inner probasidial cells; pedicel multihyphal.

Additional specimens examined: South Africa, Gauteng, ARC Roodeplaat, on leaves of Vachellia karroo, 22 May 2012, M. Ebinghaus (ME139), paratype PREM60809; 31 May 2012, M. Ebinghaus (ME153), paratype KRM0006615; KwaZulu-Natal, Charters Creek, on leaves of V. natalitia, 19 March 2013, M. Ebinghaus (ME214), paratype PREM61021.

Notes: Sydow and Sydow (1912) described the uredinia as subepidermal but our microscopic examinations did not support this finding and we rather observed subcuticular sori. We further observed 10-12 scattered or bizonate germ pores in the urediniospores, while Sydow and Sydow (1912) noted the presence of 6-8 scattered germ pores. Arguably, the most important emendation concerns the surface structure of these spores that show a distinct "hub and spoke pattern" (Fig. 14b and e; see for definition also Gardner and Hodges 1985).

Ravenelia pretoriensis is morphologically similar to $R$. modesta and both species appeared to be closely related in our phylogenetic analyses based on fragments of the LSU and $\mathrm{CO} 3$ gene regions (Figs. 1 and 3). However, $R$. pretoriensis appeared to be confined to Vachellia karroo and to the closely related $V$. natalitia, while $R$. modesta was never observed on these host trees. Vachellia natalitia is here reported as a new host species for this rust fungus.

\section{New host report}

Ravenelia inornata (Kalchbr.) Dietel, Hedwigia 33: 52 \& 61. 1894 (Fig. 15a-f) 
Fig. 15 Ravenelia inornata. a Aecidia on a leaflet of Vachellia karroo. b LM of aeciospores. c $S E M$ of an aecium intermingled with a telium. d SEM of rectangular aeciospores showing verrucose ornamentations. e SEM of a subepidermal telium. f SEM of teliospores. Scale bars: $\mathbf{a}=$ $0.5 \mathrm{~mm} ; \mathbf{b}$ and $\mathbf{f}=20 \mu \mathrm{m} ; \mathbf{c}$ and $\mathbf{e}=50 \mu \mathrm{m} ; \mathbf{d}=4 \mu \mathrm{m}$
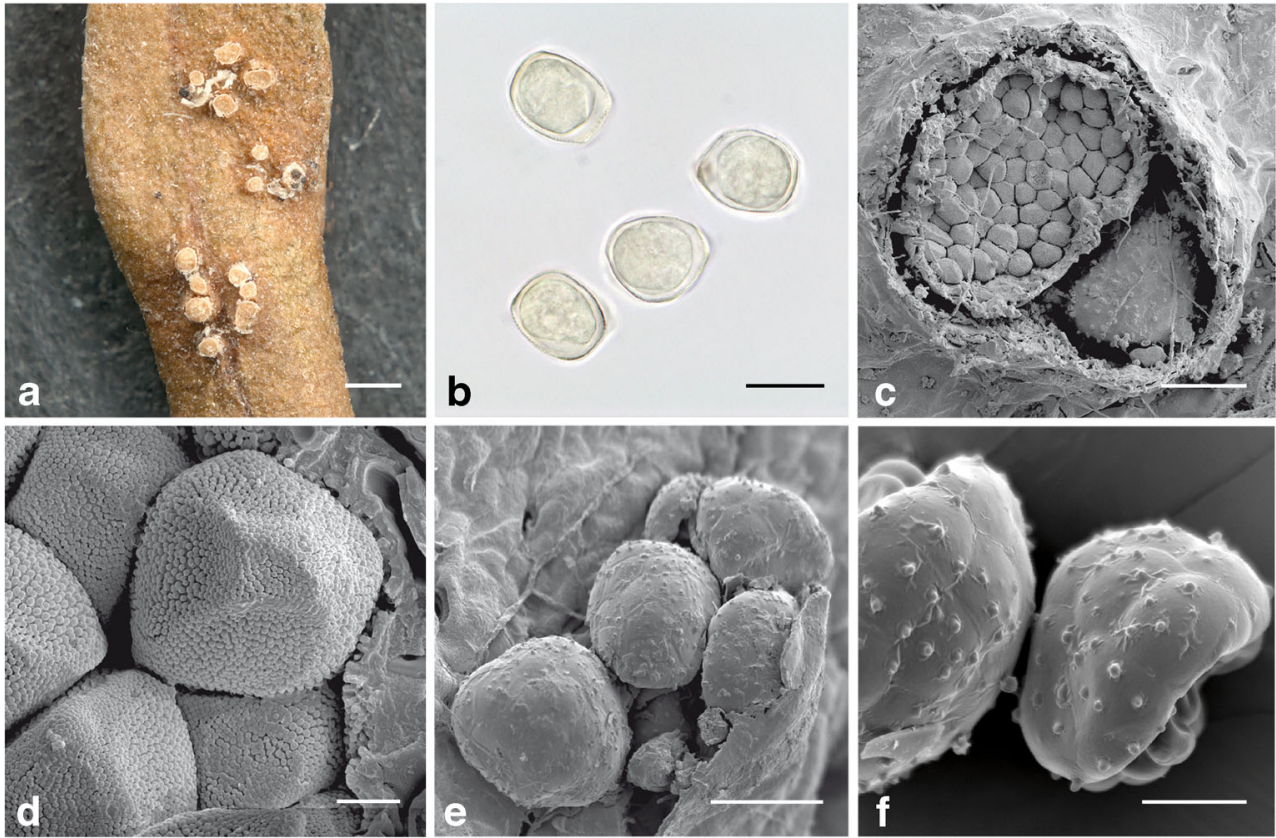

Type: South Africa, Eastern Cape, Somerset East, Jan 1881, on leaves of Acacia karroo Hayne (Vachellia karroo (Hayne) Banfi \& Galasso), P. MacOwan, holotype (PREM20734).

Spermogonia not seen. Aecia hypophyllous on leaflets, scattered or in small groups, subepidermal, peridium cylindrical, up to $500 \mu \mathrm{m}$ in length, yellow white; aeciospores subhyaline to pale yellow, rectangular to subglobose, $23-27 \times 19-22 \mu \mathrm{m}$, spore wall densely verrucose, 1-3 $\mu \mathrm{m}$, but distinctly thickened in the angles up to $6 \mu \mathrm{m}$; telia minute, scattered or in small groups, mixed with the aecia, sometimes telia developing within or confluently with the aecia, dark brown to almost black; teliospores subcircular or irregular circular shaped from above, upper side of teliospores convex, often irregularly shaped, chestnut brown to dark brown, variable in size, 104-162 $\mu \mathrm{m}$ in diameter with 8-12 single probasidial cells across, probasidial cells single layered, (32)36-50 $(52) \times(12) 14-17(19) \mu \mathrm{m}$, cell wall thickened at the top side of the spore, (3)5.5-8.5(11) $\mu \mathrm{m}$, each probasidial cell bearing a variable number (up to seven) small verrucae, 1-3 $\mu \mathrm{m}$ in height; cysts pendent, hyaline, smooth, number of cysts equal to the number of the probasidial cells, swelling in water but only slightly in lactophenol solution; pedicel multihyphal.

Additional specimens examined: South Africa, Mpumalanga, South of Barberton, on leaves of V. natalitia, 2 June 2012, M. Ebinghaus (ME158), PREM61214; KwaZulu-Natal, close to St. Lucia, 9 March 2013, M. Ebinghaus (ME215), KR-M-0006613; Eastern Cape,
Kentani, on leaves of A. karroo Hayne, 3 June 1912, A. Pegter (PREM2368); 23 July 1912, A. Pegter (PREM2541).

Notes: Based on collections deposited at the National Mycology Collections (Roodeplaat, South Africa) and our observations, this species appears to have a distribution range in South Africa that is restricted to the southern and southeastern coastal regions and up to the low lying regions of southern Mpumalanga Province. Interestingly, $R$. inornata appeared to be absent in the central plateau region of South Africa despite the common occurrence of its host trees (Coates Palgrave 2005). This region is climatically distinct in having lower levels of precipitation and a pronounced dry season. The absence of $R$. inornata in this region might be linked to these environmental factors.

This species shares the hosts $V$. natalitia and V. karroo with $R$. pretoriensis and $R$. macowaniana. Mixed infections by these two species were thus occasionally encountered even on a single leaflet. Co-occurrence of $R$. inornata with $R$. pretoriensis may lead to confusion because the teliospores of both rusts bear verrucose ornamentations. However, the teliospores differ distinctly in size with teliospores of $R$. pretoriensis mostly measuring 70-95 $\mu \mathrm{m}$, while the teliospores of $R$. inornata range between 104 and $162 \mu \mathrm{m}$ (Table S2). They can furthermore be distinguished by their life cycles: Ravenelia pretoriensis might be hemicyclic as only the uredinial and the telial stages are known while $R$. inornata appears demicyclic. All three species are only distantly related in molecular phylogenetic analyses (Figs. 1 and 3). 


\section{Key to South African Ravenelia species}

- 1. Galls/malformations of host tissues .2

- $\quad 1 *$. No galls/malformations visible, also no old galls .....6

- 2. Galls/malformations caused by aecia

- $2 *$. Galls caused by aecia bearing echinulate aeciospores; reported on $S$. polyacantha subsp. campylacantha. .R. modjadji

- 3. Teliospores smooth or with rare verrucae

- $\quad 3 *$. Teliospores spinescent $R$ evansi

- 4. Teliospores $<85 \mu \mathrm{m}$ 5

- $\quad 4^{*}$. Teliospores up to $130 \mu \mathrm{m}$; reported on Vachellia karroo, V. natalitia, V. permixta...........R. macowaniana

- Telia $0.1-0.2 \mathrm{~mm}$, on leaflets; reported on $V$. xanthophloea...... .R. xanthophloeae

- $5^{*}$. Telia crustaceous, pedicels of teliospores up to $180 \mu \mathrm{m}$ long; teliospores $<60 \mu \mathrm{m}$. R. natalensis

- 6. On Vachellia ... 7

- 6*. On Mimosoideae other than Vachellia, or on Faboideae or Caesalpinioideae

- 7. No urediniospores; peridiate aecia on leaves; teliospores verrucose. R. inornata

- $\quad 7 *$. Urediniospores often present; no aecia, if present teliospores spinescent.

\section{...8}

- 8. Urediniospores echinulate; teliospores spinescent; reported on $V$. nilotica....................R. acaciae-arabicae

- $8 *$. Urediniospores with "hub \& spoke" pattern ............. 9

- 9. Teliospores verrucose to spinescent; reported on $V$. karroo and $V$. natalitia.

R. pretoriensis

- $9 *$. Teliospores distinctly spinescent; reported on $V$. rehmanniana, $V$. hebeclada, V. luederitzii, V. gerrardii..... R. modesta

- 10. On Senegalia. 18

- $10 *$. On a different host plant genus.............................. 11

- 11. Teliospores smooth or with only few ornaments...... 12

- 11 *. Teliospores distinctly ornamented........................ 15

- 12. Teliospores smooth, sometimes with single papillae, up to 3-4 $\mu \mathrm{m}$; reported on Senna ...............R. mesilliana

- $12 *$. On a different host plant genus................. 13

- 13. Teliospores $>115 \mu \mathrm{m}$, smooth or with solitary verrucae..................................... 14

- $13^{*}$. Teliospores up to $105 \mu \mathrm{m}$, smooth; reported on Elephantorrhiza......................R. elephantorhizae

- 14. Uredinia aparaphysate; probasidial cells 2-layered; reported on Calpurnea ........................................ glabra

- $\quad 14 *$. Uredinia with numerous clavate paraphyses; teliospores with few solitary verrucae, $115-140 \mu \mathrm{m}$................R. woodii

- 15. Teliospores with pronounced clavate papillae, up to $8 \mu \mathrm{m}$ long; reported on Abrus.

R. ornata

- $15^{*}$. Teliospores $<70 \mu \mathrm{m}$, with distinct spines; reported on Albizia.

R. minima
- $15 * *$. on a different host plant genus.................. 16

- 16. Teliospores spinescent; probasidial cells 1 layered; reported on Dichrostachys cinerea..........R. dichrostachydis

- $\quad 16 *$. On a different host plant genus................. 17

- 17. Teliospores with papillae; uredinia aparaphysate; reported on Mundulea sericea....................... stictica

- $17 *$. Teliospores with papillae, 4-7 $\mu \mathrm{m}$ long; reported on Indigofera.................................... indigoferae

- $17^{* *}$. Teliospores verrucose, up to $2 \mu \mathrm{m}$ long; reported on Tephrosia...................................... tephrosiae

- 18. On S. mellifera..................................... 19

- 18*. On a different host plant species.................. 20

- 19. Teliospores smooth...................... transvaalensis

- 19*. Teliospores spinescent........................ spinifera

- 20. Teliospores smooth or rarely with solitary papillae; urediniospores with 13-15 scattered germ pores; reported on $S$. ataxacantha.

R. halsei

- 20*. Teliospores smooth, verrucose or spinescent; urediniospores with 4-6 equatorially arranged germ pores; on a different host plant species.................................. 21

- 21. On $S$. caffra .......................................................... 22

- $21 *$. On a different host plant species ........................ 23

- 22. Teliospores smooth............................ peglerae

- $22 *$.Teliospores verrucose......................... pienaarii

- 23. Teliospores spinescent; only few paraphyses present in uredinia; reported on $S$. nigrescens.....R. acaciae-nigrescentis

- $23 *$. Teliospores smooth; uredinia with numerous intrasoral paraphyses; reported on S. senegal (both subspecies)......................................... acaciicola

- $23 * *$. Teliospores verrucose; uredinia aparaphysate; on S. burkei.................................... R. escharoides

- $23 * * *$. Teliospores verrucose; only few paraphyses present in uredinia; reported on $S$. polyacantha subsp. polyacantha.................................................. doidgeae

- $23 * * * *$. Teliospores with small verrucae; uredinia with peripheral paraphyses; reported on $S$. galpinii.................................. molopa

- $23 * * * * *$. Teliospores verrucose; uredinia with peripheral paraphyses; reported on $S$. erubescens. R. moloto

\section{Discussion}

In the present study, we analyzed numerous Ravenelia specimens with a strong focus on South African species, but included also species from the Neotropics as well as published gene sequences. The South African representatives clustered in seven phylogenetic lineages, one of which was represented by a single species only (clade III). Two of these phylogenetic groups consist only of Paleotropic species while five of these 
groups consist of Neotropic and Paleotropic species. Two lineages were found that are of exclusively Neotropical origin and were therefore not highlighted in the phylogenetic trees. In the following sections, the findings of the molecular phylogenetic analyses will be discussed with emphasis on morphological and life cycle traits as well as a consideration of the evolutionary ecological implications relating to host specialization. Finally, the diversity and taxonomy of Ravenelia in South Africa is re-evaluated.

\section{Morphology and life cycle traits linked to phylogenetic lineages}

Clade I The species in this clade comprised only South African representatives and are exlusively parasitizing species of the genus Senegalia (Mimosoideae). They were often difficult to discriminate from each other based on urediniospore or teliospore morphology. Nevertheless, the species could be distinguished by molecular phylogenetic analyses and, in addition, showed distinct host preferences. Rusts that shared teliospore traits like a specific ornamentation type tended to represent distinct lineages that mirror their close phylogenetic relationships, e.g., $R$. acacia-nigrescentis and $R$. spinifera (spinescent teliospores), $R$. moloto, $R$. doidgeae and $R$. modjadji (verrucose teliospores) or $R$. transvaalensis and $R$. acaciicola (smooth teliospores). For species in this clade, only uredinia and telia are known and therefore, they may be hemicyclic. The only exception is here $R$. modjadji. This species produces gall-inducing primary uredinia as well as secondary uredinia.

Clade II This clade was comprised of both Paleotropical and Neotropical species. The South African $R$. modesta and $R$. pretoriensis share a unique urediniospore surface structure with the Neotropical species in this clade that was described as "hub and spoke pattern" (Gardner and Hodges 1985, Hernández and Hennen 2002, see Fig. 14b and e) and appears to be synapomorphic for this lineage. This urediniospore ornamentation had previously only been reported for a few Ravenelia species from the Neotropics. The African representatives in this clade were only found on Vachellia species, while the South American species had been collected from Vachellia and Mimosa. Further rust species with this character have been reported from other host genera within the Mimosoideae but mostly on Albizia including $R$. albiziaezygiae, $R$. albiziicola, $R$. clemensae among others. Field observations suggested that the uredinial stage of $R$. pretoriensis and $R$. modesta is consistently the predominant spore stage, with the teliospores observed more rarely. This finding was irrespective of the time point of species sampling and may represent a lineage-specific life cycle characteristic.

Clade III This clade consisted of a single species, $R$. dumeti. Only the uredinial stage is known of this species and specific traits are thus limited to characterize this rust. The numerous intrasoral and distinctly capitate paraphyses distinguish it from all other Ravenelia species investigated in the present study. The extended branch length in the phylogenetic trees that separates this lineage from its sister group of clade II mirrors the distinctiveness of these uredinial traits. Ravenelia dumeti is the only Ravenelia species of southern African origin that parasitizes a species of a lineage of Senegalia with African-American distribution, while all Senegalia rusts of clade I are parasitic on a hosts lineage of an African-Asian distribution (Bouchenak-Khelladi et al. 2010; Kyalangalilwa et al. 2013). In this respect, $R$. dumeti is more similar to the Ravenelia species studied from South America (Fig. 2), which also parasitize on hosts belonging to this African-American lineage of Senegalia.

Clade IV The members of this clade are heterogeneous in terms of morphology and associated hosts as they parasitize representatives of the two traditionally recognized subfamilies Caesalpinioideae and Mimosoideae. Here, R. halsei (on Senegalia, Mimosoideae) is the only species with aparaphysate uredinia, while $R$. elephantorhizae (on Elephantorrhiza, Mimosoideae), $R$. macrocarpa, and $R$. mesilliana (both on Senna, Caesalpinioideae) have intrasoral paraphyses. In the latter two species, the paraphyses are variable in size and shape (Baxter 1965, Hernández and Hennen 2002; Fig. 11). Senna spp. are hosts to approximately 14 species of Ravenelia and are thus an important host group for these rusts (www.indexfungorum.org). Future studies should clarify whether size variation of the paraphyses is a common morphological character that is synapomorphic for Ravenelia species parasitizing Senna.

Clade V Ravenelia holwayi and $R$. dichrostachydis share the host preference for Mimosoideae but show several striking differences and a significant genetic distance reflecting their distant geographic origin from North America and South Africa, respectively. Most prominently, the species differ in the ability of $R$. holwayi to induce uredinial galls while $R$. dichrostachydis does not share this trait. To date, only $R$. dichrostachydis is known from Dichrostachys while six Ravenelia species have been described on Prosopis, e.g., $R$. arizonica, $R$. chacoensis, $R$. prosopidis, or $R$. spicigerae (www.indexfungorum.org). The incorporation of these species in future analyses could help to characterize members of this clade in more detail.

Clade VI This is the only lineage comprising Ravenelia species infecting members of the Faboideae suggesting that this host association evolved only once. This is in contrast to the Ravenelia spp. parasitizing on Mimosoideae, which are present in several lineages of the phylogenetic tree and thus of polyphyletic origin. Within this clade, only uredinial and telial 
stages are known for $R$. stictica, R. glabra, R. aff. indigoferae, and $R$. tephrosiae suggesting a hemicyclic life cycle. They are furthermore characterized by two-layered probasidial cells. Since the type species of Ravenelia, R. epiphylla, was collected on a related host of the Faboideae and also shares these characters, we assume that it would reside within this phylogenetic group. Unfortunately, fresh material of $R$. epiphylla was not available for inclusion in the molecular phylogenetic studies and its relationship to other species could thus not be resolved.

In our analyses, Ravenelia ornata was the sister species to R. platensis. Both species develop uredinioid aecia (Hernández and Hennen 2002; Wood 2006), a trait that is shared with several distinct lineages of Ravenelia rusts, i.e., the neotropical $R$. echinata var. ectypa, $R$. havanensis and $R$. hermosa but also R. holwayi in clade V (Fig. 2). However, $R$. ornata apparently lacks the ability to induce galls. The two accessions of this rust collected in South Africa showed considerable sequence variation of $3.8 \%$ (6.6\% when gaps are included) within a fragment of the LSU gene region, even though they are morphologically indistinct based on teliospore morphology (data not shown). Interestingly, collections indicate a wide distribution within the tropics with this rust being reported from the Caribbean, Asia, and Africa (Farr and Rossman 2017). These findings suggest that a broader sampling including specimens from its full geographical range could reveal a species complex including cryptic species.

Clade VII The rusts in this phylogenetic group are confined to Mimosoideae, mainly Vachellia species with the exception of two neotropically distributed rusts, i.e., $R$. mainsiana and $R$. cebil infecting Mimosa and Anadenanthera, respectively. Several species in this clade possess two-layered probasidial cells, a feature shared with Ravenelia spp. on Faboideae (clade VI), and most species are able to induce galls (Fig. 2). No spermogonia were reported for those species within the group (R. acacia-arabicae, R. mainsiana, R. cebil, R. inornata) lacking the ability of gall induction. This is in line with observations of Larous and Lösel (1993) that invasion of the vascular system and resulting hypertrophies are only induced by the monokaryotic hyphae of the rust fungi. Remarkable differences in life cycle traits were seen between Ravenelia hieronymi and the closely related $R$. evansii, R. macowaniana, and $R$. xanthophloeae by producing telia subsequently on aecial galls in the case of $R$. hieronymi (Hernández and Hennen 2003, Hennen et al. 2005). Hennen et al. (2005) suggested that $R$. hieronymi could represent a demicyclic rust as pedicellate urediniospores were never observed. This is in contrast to the macrocyclic $R$. evansii, R. macowaniana, and $R$. xanthophloeae that induce aecial galls but in which the uredial and telial stages are always spatially separated from the aecia (Doidge 1939; Ebinghaus et al. 2018). While the aeciospores of these rusts obviously re-infect the host, the aeciospores of
R. hieronymi were suggested to be non-functional (Hernández and Hennen 2003; Hennen et al. 2005). Similar to $R$. hieronymi, only aecia and telia are known for $R$. inornata and they develop intermingled with the aecia, but galls are unknown in this species. However, the two species did not appear to be closely related in our phylogenetic analyses. In the acacia rust Atelocauda koae simultaneously occurring aecio- and teliospores are known to be non-functional and an ongoing transition from demicyclic to microcyclic life cycle has been suggested (Hodges Jr and Gardner 1984, Chen et al. 1996). It remains an open question as to whether this also holds true for R. inornata. Dietel (1906) did not observe germpores in this rust and this could support the view of non-functional aeciospores.

Linking morphological traits to phylogenetic lineages within Ravenelia showed that taxonomic systems as proposed by several authors including Long (1903), Dietel (1906), Sydow and Sydow (1915), and Sydow (1921) were often not congruent with the phylogenetic reconstructions based on LSU and $\mathrm{CO} 3$ gene regions (Fig. 2, Table S1). Rust fungal structures including the morphology of uredinio- and teliospores have been suggested to be highly adaptive and are consequently prone to convergent evolution (Savile 1971, 1976, 1978). Additionally, our finding of close phylogenetic relationship between Ravenelia species that show different life cycle traits highlights the variability of those character states in the rust fungi as has been shown many times before (compare Maier et al. 2007). Nevertheless, several traits such as the host association but also the ability to induce galls in combination with the development of two-layered probasidial cells were found to represent useful criteria to draw conclusions regarding monophyly. In this respect, we found evidence that the macrocyclic and often gall-inducing rusts comprising those on Vachellia but also other members of the Mimosoideae most likely represent a more ancestral lineage in Ravenelia (Shattock and Preece 2000). Likewise, the "hub and spoke" urediniospore ornamentation pattern appeared synapomorphic for a distinct lineage of Ravenelia species.

\section{Evolutionary ecological implications}

Species of Senegalia and Vachellia represent the majority of Ravenelia hosts in South Africa.

Two major lineages of Senegalia rusts had either an exclusively Paleotropic (clade I) or Neotropic (i.e., R. cohniana, $R$. piepenbringiae, and $R$. hernandezii; compare Ebinghaus and Begerow 2018) distribution. Molecular dating analyses suggest a split of Senegalia species into an Asian-African lineage from American ancestors in the late Miocene, some 18-9 Mya (Bouchenak-Khelladi et al. 2010). The Paleotropic lineage is believed to have subsequently diversified in response to oscillating climatic changes during the Pliocene and species likely spread from Africa into Asia (Bouchenak-Khelladi et al. 
2010). The Paleotropically distributed rusts in clade I correspond to this host lineage and reasonably explains the AsianAfrican distribution of R. acaciicola (Fig. 2). The ancestor of this rust lineage could have jumped from a non-Senegalia host onto an early representative of the diverging African host lineage and diversified simultaneously with the diverging hosts by cospeciation or subsequently via host tracking coevolution (Ehrlich and Raven 1964; Janz and Nylin 1998). In the latter case, the parasite would have overcome host defense of an ancestral host and, following its radiation, colonized and diversified on these related species of the same clade. These two possible scenarios could be assumed for $R$. modjadji, R. moloto and $R$. doidgeae that infect the sister species $S$. polyacantha subsp. campylacantha, S. polyacantha subsp. polyacantha, and $S$. erubesens, respectively (Bouchenak-Khelladi et al. 2010; Kyalangalilwa et al. 2013). Other members of this rust lineage might rather have evolved by host shifts (Roy 2001), e.g., $R$. transvaalensis or $R$. spinifera that both infect $S$. mellifera subsp. detinens.

The results of the present study further suggest that the Ravenelia species occurring on Senegalia represented in clade I are highly host specific, with most species restricted to a single host. The hosts of the rusts in this clade predominantly occur in the semi-arid savannas of South Africa where they occupy specific niches and form dominant floral elements (Coates Palgrave 2005, Smit 2008). This native semi-arid habitat could also have contributed to a predominance of the more heat- and drought-resistant telial stage compared with the uredinial stage (Savile 1976).

The limited numbers of wind-dispersed urediniospores as well as the obvious lack of spermogonia and the aecial stage in these Ravenelia spp. may imply that rust fungal propagules are restricted from easy movement to a broader range of potential hosts due to dispersal limits. This may have hampered them from acquiring multiple hosts.

Several rust fungi that lack spermogonia were found to reproduce sexually through self-fertility (Anikster et al. 1980; Anikster and Wahl 1985; Ono 2002). If this is also true for the Senegalia rusts, the dispersal limits and the resulting restrictions in gene flow between populations may reasonably explain the observed host ranges but could also have led to an increased speciation rate. On the other hand, apomictic or asexual reproduction was proven to occur in various microcyclic species (Ono 2002) and which potentially can lead to similar speciation patterns. However, examinations of nuclear behavior as well as population genetic approaches are needed to prove either mechanism.

Species in the genus Vachellia (formerly Acacia subsp. Acacia) represent the other major host group for the South African Ravenelia species. Our study clearly showed that the rusts infecting this host genus evolved at least twice independently. The gall-inducing macrocyclic rusts $R$. macowaniana and $R$. evansii are among the most abundant rust fungi in southern Africa. This is also consistent with their wide host range and common occurrence of their hosts (Smit 2008). In contrast to the observations in the south African gall rusts, populations of macrocyclic rust fungi were reported to often lose their aecial stage in more arid environments. Savile interpreted this as an adaptation to low water availability and high UV radiation, because aeciospores often possess little pigmentation and thin spore walls (Savile 1971, but see Zwetko and Pfeifhofer 1991). However, we can only speculate under which conditions these rusts have evolved the capacities to induce aecial galls and whether or not ontogenic constraints may restrict life cycle reductions. But considering the scattered distributions of their hosts in open savannas and in the Karoo semi-desert, the massive production and release of wind-borne aeciospores may be still advantageous by effectively bridging the distance between potential host individuals. The production of spermatia and large numbers of aeciospores could also contribute to the wide host range observed in $R$. macowaniana and $R$. evansii, with greater numbers of potential hosts being exposed to these spores. The South African and gall-inducing Vachellia rusts could thus have evolved a different strategy compared with Ravenelia species on Senegalia to persist and disperse in a similar environment.

The Vachellia rusts exhibiting urediniospores with "hub and spoke" ornamentation (clade II) most likely originated in the Neotropics. This emerges from the fact that several Ravenelia species displaying this morphological characteristic infect a suite of different mimosoid genera with a Neotropical distribution. We thus assume that an ancestor of $R$. modesta and $R$. pretoriensis was introduced to Africa by long-distance dispersal. Spore dispersal over long distances may readily occur and was shown for other rust fungi like Melampsora species (e.g., Barrès et al. 2008). The origin of the African lineage could have coincided with the trans-Atlantic dispersal events that were argued to have occurred in the Vachellia species in the Miocene (16-11 mya; Bouchenak-Khelladi et al. 2010). Ravenelia modesta and $R$. pretoriensis are difficult to distinguish from each other based on spore morphology or the genetic markers utilized in this study and speciation most likely occurred more recently.

These findings and the fact that Ravenelia species parasitizing the major host genera Vachellia and Senegalia appear in several phylogenetic lineages suggest that diversification of Ravenelia in the current circumscription might have been driven by a combination of host shifts and co-evolutionary host tracking or cospeciation in addition to more rare jumps to co-occurring but more distantly related hosts. This situation might be comparable with patterns observed within Puccinia and Uromyces where a similar situation was observed for the species parasitizing Cyperaceae and Poaceae in relation to all other parasitized groups (Maier et al. 2007; van der Merwe et al. 2007, 2008). 
Table 2 List of Ravenelia species and their hosts reported in South Africa

Fungus Host

Ravenelia acaciae-arabicae

Ravenelia acaciae-nigrescentis

Ravenelia acaciicola

Ravenelia deformans

Ravenelia dichrostachydis

Ravenelia doidgeae

Ravenelia dumeti

Ravenelia elephantorhizae

Ravenelia escharoides

Ravenelia evansii

Ravenelia glabra

Ravenelia halsei

Ravenelia aff. indigoferae

Ravenelia inornata

Ravenelia macowaniana

Ravenelia mesilliana

Ravenelia minima

Ravenelia modesta

Ravenelia modjadji

Ravenelia molopa

Ravenelia moloto

Ravenelia natalensis

Ravenelia ornata

Ravenelia peglerae

Ravenelia pienaarii

Ravenelia pretoriensis

Ravenelia spinifera

Ravenelia stictica

Ravenelia tephrosiae

Ravenelia transvaalensis

Ravenelia woodii

Ravenelia xanthophloeae
Host

Vachellia nilotica subsp. kraussiana (Benth.) P.J.H.Hurter \& Mabb.

Senegalia nigrescens (Oliv.) P.J.H. Hurter

Senegalia senegal var. leiorhachis (L.) Britton

Senegalia senegal var. rostrata (L.) Britton

Undetermined acacia (aff. V. nilotica)

Dichrostachys cinerea (L.) Wight \& Arn.

Senegalia polyacantha subsp. polyacantha (Willd.) Seigler \& Ebinger

Senegalia brevispica (Benth.) Kyal. \& Boatwr.

Elephantorrhiza elephantina (Burch.) Skeels, E. burkei Benth.

Senegalia burkei (Benth.) Kyal. \& Boatwr.

Vachellia borleae (Burtt Davy) Kyal. \& Boatwr.

Vachellia davyi (N.E.Br.) Kyal. \& Boatwr.

Vachellia exuvialis (Verdoorn) Kyal. \& Boatwr.

Vachellia hebeclada subsp. hebeclada (DC.) Kyal. \& Boatwr.

Vachellia luederitzii var. retinens (Sim) Kyal. \& Boatwr.

Vachellia robusta subsp. robusta (Burch.) Kyal. \& Boatwr.

Vachellia sieberiana subsp. woodii (Burtt Davy) Kyal. \& Boatwr.

Vachellia swazica (Burtt Davy) Kyal. \& Boatwr.

Vachellia gerrardii (Benth.) P.J.H.Hurter

Vachellia rehmanniana (Schinz) Kyal. \& Boatwr.

Calpurnia sylvatica E. Mey.

Senegalia ataxacantha (DC.) Kyal. \& Boatwr.

Indigofera $\mathrm{sp.} \mathrm{L.}$

Vachellia karroo (Hayne) Banfi \& Galasso

Vachellia natalitia (E.Mey.) Kyal. \& Boatwr

Vachellia karroo (Hayne) Banfi \& Galasso

Vachellia natalitia (E.Mey.) Kyal. \& Boatwr

Vachellia permixta (Burtt Davy) Kyal. \& Boatwr.

Senna bicapsularis (L.) Roxb.

Albizia adianthifolia (Schumach.) W.F.Wight

Vachellia gerrardii (Benth.) P.J.H.Hurter

Vachellia luederitzii var. retinens (Sim) Kyal. \& Boatwr.

Vachellia rehmanniana (Schinz) Kyal. \& Boatwr.

Senegalia polyacantha subsp. campylacantha (Hochst. ex. A.Rich.) Kyal. \& Boatwr.

Senegalia galpinii (Burtt Davy) Seigler \& Ebinger

Senegalia erubescens (Welw. ex Oliv.) Kyal. \& Boatwr.

Vachellia karroo (Hayne) Banfi \& Galasso

Abrus precatorius L.

Senegalia caffra (Thunb.) P.J.H.Hurter \& Mabb.

Senegalia caffra (Thunb.) P.J.H.Hurter \& Mabb.

Vachellia karroo (Hayne) Banfi \& Galasso

Senegalia mellifera subsp. d etinens (Burch.) Kyal. \& Boatwr.

Mundulea sericea (Willd.) A. Chev.

Tephrosia heckmanniana Harms

Tephrosia macropoda var. macropoda (E. Mey) Harv.

Senegalia mellifera subsp. detinens (Burch.) Kyal. \& Boatwr.

Fabaceae undetermined

Vachellia xanthophloea (Benth.) P.J.H.Hurter 


\section{Diversity of Ravenelia in South Africa}

A targeted sampling effort in combination with morphological investigations and molecular phylogenetic analyses revealed that the diversity of Ravenelia species in South Africa greatly exceeds the current knowledge regarding the diversity of this genus in the region. Six Ravenelia species were revealed as new to science and five Ravenelia species were new reports for South Africa. In another recent study, one new Ravenelia species and seven new acacia hosts were reported from the same region (Ebinghaus et al. 2018). Thus, to date, 32 species of Ravenelia are known for South Africa. With a total of 25 species, the majority of Ravenelia spp. are confined to the traditionally recognized host subfamily Mimosoideae (in the classic sense). Of these, 13 species occur on 13 Senegalia hosts, 9 on 15 Vachellia hosts, and 3 on host trees of various other mimosoid genera. Five species occur on Faboideae hosts and a single rust species ( $R$. mesilliana) is known on Senna (Caesalpinioideae) (Table 2). A single species (R. woodii) was collected from an undetermined leguminous host plant (Doidge 1939). Unfortunately, this monotypic rust is not represented in PREM and could not be investigated.

A special effort was made to investigate all of the approximately 42 species of acacias (18 taxa of Senegalia and 24 taxa of Vachellia) in South Africa (Coates Palgrave 2005; Smit 2008) and scrutinize them for infections. With 22 described Ravenelia spp. on at least 28 acacias the genera Senegalia (13 host taxa; $72 \%$ of total species) and Vachellia (15 host taxa; $62.5 \%$ of total species) represent the major hosts of this genus in South Africa (Table 2). Based on the number of herbarium specimens present at PREM and our own observations, some of these rusts, e.g., $R$. macowaniana and $R$. evansii likely represent the most abundant and ecologically significant rust fungal species on acacias in this region.

A total of 161 Vachellia species and 203 species of Senegalia have been described globally (Maslin et al. 2003). Of these, only approximately 26 and 37 species, respectively, were reported as hosts of Ravenelia spp. (www. indexfungorum.org). Considering the high percentage of host taxa we found within the genera Senegalia and Vachellia in South Africa, it is likely that future studies on Ravenelia will significantly exceed species numbers currently known for this genus.

\section{Conclusion}

In this study, we have revised and illustrated the diversity of Ravenelia spp. in South Africa. The first molecular phylogenetic analysis is also presented for this genus. Based on phylogenetic reconstructions, it was possible to consider aspects of the presumed evolutionary strategies in Ravenelia spp. that reflect lineage-specific host association patterns and the biogeography of their hosts. It appears worthwhile for future research in these rust fungi to focus on a global species sampling including rusts especially collected from the Caesalpinioideae and Faboideae as well as to incorporate additional members of the family Raveneliaceae. These are likely to shed light on evolutionary pathways aiding to a more comprehensive understanding of the evolution of character states in the rust fungi.

Acknowledgments We are grateful to Dr. Isabel Rong, Dr. Elna van der Linde, Dr. Riana Jacobs, and Mrs. Ros Urban (Plant Protection Research Institute, ARC Roodeplant) for their generous support, field guidance, and for giving access to the National Collection of fungi (PREM).

Funding information Open Access funding provided by Projekt DEAL. This study was supported by the German Research Foundation (DFG), the Federal Ministry of Education and Research (BMBF), Studienstiftung für mykologische Systematik und Ökologie, and the German Academic Exchange Service (DAAD).

\section{Compliance with ethical standards}

Conflict of interest The authors declare that they have no conflict of interests.

Open Access This article is licensed under a Creative Commons Attribution 4.0 International License, which permits use, sharing, adaptation, distribution and reproduction in any medium or format, as long as you give appropriate credit to the original author(s) and the source, provide a link to the Creative Commons licence, and indicate if changes were made. The images or other third party material in this article are included in the article's Creative Commons licence, unless indicated otherwise in a credit line to the material. If material is not included in the article's Creative Commons licence and your intended use is not permitted by statutory regulation or exceeds the permitted use, you will need to obtain permission directly from the copyright holder. To view a copy of this licence, visit http://creativecommons.org/licenses/by/4.0/.

\section{References}

Altschul SF, Gish W, Miller M, Myers EW, Lipman DJ (1990) Basic local alignment search tool. J Mol Biol 215:403-410

Anikster Y, Wahl I (1985) Basidiospore formation and self-fertility in Puccinia mesnieriana. Trans Br Mycol Soc 84:164-167

Anikster Y, Moseman JG, Wahl I (1980) Development of basidia and basidiospores in Uromyces species on wild barley and Liliaceae in Israel. Trans Br Mycol Soc 75:377-382

Baccarini P (1917) Fungi etiopici. Ann Bot 14:128

Barrès B, Halkett F, Dutech C, Andrieux A, Pinon J, Frey P (2008) Genetic structure of the poplar rust fungus Melampsora laricipopulina: evidence for isolation by distance in Europe and recent founder effects overseas. Infect Genet Evol 8:577-587

Baxter JW (1965) Studies of North American species of Ravenelia. Mycologia 57:77-84

Berkeley (1853) Ravenelia gen. nov. Gard Chron, London:132

Boa E and Lenné JM (1994) Diseases of nitrogen fixing trees in developing countries. An annotated list. Natural Ressources Institute (NRI), Kent 
Bouchenak-Khelladi Y, Maurin O, Hurter J, van der Bank M (2010) The evolutionary history and biogeography of Mimosoideae (Leguminosae): an emphasis on African Acacias. Mol Phylogenet Evol 57:495-508

Chen W-Q, Gardner DE, Webb DT (1996) Biology and life cycle of Atelocauda koae, an unusual demicyclic rust. Mycoscience 37:9198

Coates Palgrave M (2005) Keith Coates Palgrave Trees of Southern Africa. edn 3, imp. 3., Struik Publishers, Cape Town

Crous PW, Rong IH, Wood A, Lee S, Glen H, Botha W, Slippers B, de Beer WZ, Wingfield MJ, Hawksworth DL (2006) How many species of fungi are there at the tip of Africa? Stud Mycol 55:13-33

Cummins GB (1959) Illustrated genera of rust fungi. Burgess Publishing Co., Minneapolis

Cummins GB, Hiratsuka Y (2003) Illustrated genera of rust fungi. Third edition. APS Press, St. Paul

Dietel P (1894) Die Gattung Ravenelia. Hedwigia 33:22-69

Dietel P (1906) Monographie der Gattung Ravenelia Berk. Beih Bot Centralbl 20:343-413

Doidge EM (1927) A preliminary study of the South African rust fungi. Bothalia 2:1-228

Doidge EM (1939) South African rust fungi III. Bothalia 3:487-512

Doidge EM (1948) South African rust fungi part 5. Bothalia 4:895-918

Doidge EM (1950) The South African Fungi and Lichens to the End of 1945. Bothalia 5:432

Ebinghaus M, Begerow D (2018) Ravenelia piepenbringiae and Ravenelia hernandezii, two new rust species on Senegalia (Fabaceae, Mimosoideae) from Panama and Costa Rica. MycoKeys 41:51-63

Ebinghaus M, Maier W, Wingfield MJ, Begerow D (2018) New host associations and a novel species for the gall-inducing acacia rust genus Ravenelia in South Africa. MycoKeys 43:1-21

Ehrlich PR, Raven PH (1964) Butterflies and plants: a study in coevolution. Evolution 18:586-608

Ellis JB, Everhart BM (1898) New Species of fungi from various Localities. Bull Torrey Bot Club 25:501-514

Farr DF, Rossman AY (2017) Fungal Databases. U.S. National Fungus Collections ARS, USDA. https://nt.ars-grin.gov/fungaldatabases/. Acessed 18 Aug 2017

Foxcroft LC, Henderson L, Nichols GR, Martin B (2003) A revised list of alien plants for the Kruger National Park. Koedoe 46:2

Gardner DE, Hodges CS (1985) Spore surface morphology of Hawaiian Acacia rust fungi. Mycologia 77:575-586

Hennen JF, Figueiredo MB, de Carvalho AA Jr, Hennnen PG (2005) Catalogue of the species of plant rust fungi (Uredinales) of Brazil. Instituto de Pesquisas, Jardim Botanico do Rio de Janeiro: Rio de Janeiro, Brazil

Hernández JR, Hennen JF (2002) The genus Ravenelia in Argentina. Mycol Res 106:954-974

Hernández JR, Hennen JF (2003) Rust fungi causing galls, witches' brooms, and other abnormal plant growths in northwestern Argentina. Mycologia 95:728-755

Hodges CS Jr, Gardner DE (1984) Hawaiian forest fungi. IV Rusts on endemic Acacia species. Mycologia 76:332-349

Janz N, Nylin S (1998) Butterflies and plants: a phylogenetic study. Evolution 52:486-502

Katoh K, Standley DM (2014) MAFFT multiple sequence alignment software version 7: improvements in performance and usability. Mol Biol Evol 30:772-780

Kyalangalilwa B, Boatwright JS, Daru BH, Maurin O, van der Bank M (2013) Phylogenetic position and revised classification of Acacia s.1. (Fabaceae: Mimosoideae) in Africa, including new combinations in Vachellia and Senegalia. Bot J Linn Soc 172:500-523

Lanave C, Preparata G, Saccone C, Serio G (1984) A new method for calculating evolutionary substitution rates. J Mol Evol 20:86-93
Larget B, Simon DL (1999) Marcov Chain Monte Carlo algorithms for the bayesian analysis of phylogenetic trees. Mol Biol Evol 16:750 759

Larous L, Lösel DM (1993) Strategies of pathogenicity in monokaryotic and dikaryotic phases of rust fungi, with special reference to vascular infection. Mycol Res 97:415-420

Lenné JM (1990) A world list of fungal diseases of tropical pasture species. Phytopathol Pap 31:120

Long (1903) The Ravenelias of the United States and Mexico. Bot Gaz $35: 111-133$

Long WH (1906) Notes on New or Rare Species of Ravenelia. J Mycol 12:233-236

Maier W, Wingfield BD, Mennicken M, Wingfield MJ (2007) Polyphyly and two emerging lineages in the rust genera Puccinia and Uromyces. Mycol Res 111:176-185

Maslin BA, Miller JT, Seigler DS (2003) Overview of the generic status of Acacia (Leguminosae: Mimosoideae). Aust Syst Bot 16:1-18

Mishra B, Thines M (2014) siMBa - a simple graphical user interface for the Bayesian phylogenetic inference programm MrBayes. Mycol Prog 13:1255-1258

Moncalvo JM, Wang HH, Hseu RS (1995) Phylogenetic relationships in Ganoderma inferred from the internal transcribed spacers and 28S ribosomal DNA sequences. Mycologia 87:223-238

Mundkur BB, Thirumalachar MJ (1946) Revisions of and additions to Indian fungi I. Mycol Pap 16:1-27

Ono Y (2002) The diversity of nuclear cycle in microcyclic rust fung (Uredinales) and its ecological and evolutionary implications. Mycoscience 43:421-439

Rambaut A (2009) FigTree, a graphical viewer of phylogenetic trees. http://tree.bio.ed.ac.uk/software/figtree

Ritschel A, Berndt R, Oberwinkler F (2007) New observations of rust fungi (Uredinales) from northern Namibia. Mycol Prog 6:137

Ronquist F, Teslenko M, van der Mark P, Ayres DL, Darling A, Höhna S, Larget B, Liu L, Suchard MA, Huelsenbeck JP (2012) MrBayes 3.2: efficient Bayesian phylogenetic inference and model choice across a large model space. Syst Biol 61:539-542

Roy BA (2001) Patterns of association between crucifers and their flower-mimic pathogens: host jumps are more common than coevolution or cospeciation. Evolution 55:41-53

Sanwal BD (1951) On some new or noteworthy Ravenelias from India. Sydowia 5:412-417

Savile DBO (1971) Coevolution of the rust fungi and their hosts. Q Rev Biol 46:211-218

Savile DBO (1976) Evolution of the rust fungi (Uredinales) as reflected by their ecological problems. Evol Biol 9:137-205

Savile DBO (1978) Paleoecology and convergent evolution in rust fungi (Uredinales). Biosystems 10:31-36

Shattock RC, Preece TF (2000) Tranzschel revisited: modern studies of the relatedness of different rust fungi confirm his law. Mycologist 14:113-117

Shivas RG, Balu A, Singh S, Ahmend SI, Dhileepan K (2013) Ravenelia acaciae-arabicae and Ravenelia evansii are distinct species on Acacia nilotica subsp. indica in India. Aust Mycol 31:31-37

Silvestro D, Michalak I (2012) raxmlGUI: a graphical front-end for RAxML. Org Divers Evol 12:335-337

Smit N (2008) Field Guide to the Acacias of South Africa. Briza Publications, Pretoria

Stamatakis A (2014) RAxML version 8: a tool for phylogenetic analysis and post-analysis of large phylogenies. Bioinformatics 30:1312 1313

Sydow (1921) Die Verwertung der Verwandtschaftsverhältnisse und des gegenwärtigen Entwicklungsganges zur Umgrenzung der Gattungen bei den Uredineen. Ann Mycol 19:161-175

Sydow H, Sydow P (1912) Beschreibungen neuer südafrikanischer Pilze - II. Ann Mycol 10:437-444 
Sydow P, Sydow H (1915) Ravenelia Berk. In: Monographia Uredinearum seu Specierum Omnium ad hunc usque Diem Descriptio et Adumbratio Systematica 3. Gebrüder Borntraeger, Leipzig, pp 225-310

Sydow H, Mitter JH, Tandon RN (1937) Fungi indici. Ann Mycol 35: 222-243

Thirumalachar (1946) Notes on three South African rust fungi. Bull Torrey Bot Club 73:346-350

Van der Merwe M, Ericson L, Walker J, Thrall PH, Burdon JJ (2007) Evolutionary relationships among species of Puccinia and Uromyces (Pucciniaceae, Uredinales) inferred from protein coding gene phylogenies. Mycol Res 111:163-175

Van der Merwe MM, Walker J, Ericson L, Burdon JJ (2008) Coevolution with higher taxonomic host groups within the Puccinia/Uromyces rust lineage obscured by host jumps. Mycol Res 112:1387-1408

van Reenen M (1995) An annotated list of Urediniomycetes (rust fungi) from South Africa 1: Melampsoraceae and Pucciniaceae, excluding Puccinia and Uromyces. Bothalia 25:173-181
Vialle A, Feau N, Allaire M, Didukh M, Martin F, Moncalvos J-M, Hemelin RC (2009) Evaluation of mitochondrial genes as DNA barcode for basidiomycota. Mol Ecol Resour 9:99-113

Vilgalys R, Hester M (1990) Rapid genetic identification and mapping of enzymatically amplified ribosomal DNA from several Cryptococcus species. J Bacteriol 172:4238-4246

Wood AR (2006) New and interesting records of southern African rust fungi (Uredinales). S Afr J Bot 72:534-543

Wood AR (2007) Rust fungi (Uredinales) on Grewia species (Tilliaceae) in South Africa, with Uredopeltis atrides comb. nov. the new name for Ravenelia atrides. Mycol Prog 6:93-99

Zwetko P, Pfeifhofer HW (1991) Carotinuntersuchungen an Rostpilzsporen. Bedeutung für die Physiologie und Taxonomie Hedwigia 52:251-266

Publisher's note Springer Nature remains neutral with regard to jurisdictional claims in published maps and institutional affiliations. 